\title{
Representation of Non-Western Cultural Knowledge on Wikipedia: The Case of the Visual Arts
}

\author{
Waqās Ahmed \\ Visiting Fellow, The Open University \\ Founding Faculty and Asst Professor, London Interdisciplinary School \\ Artistic Director, The Khalili Collections \\ Steering Panel, Art UK \\ (corresponding author)
}

\section{Dr Martin Poulter}

Wikimedian-in-Residence at the Khalili Collections

\section{Abstract}

We explore gaps in Wikipedia's coverage of the visual arts by comparing the representation of 100 artists and 100 artworks from the Western canon against corresponding sets of notable artists and artworks from non-Western cultures. We measure the coverage of these two sets of topics across Wikipedia as a whole and for its individual language versions. We also compare the coverage for Wikimedia Commons and Wikidata, sister-projects of Wikipedia that host digital media and structured data. We show that all these platforms strongly favour the Western canon, giving many times more coverage to Western art. We highlight specific examples of differing coverage of visual art inside and outside the Western canon. We find that European language versions of Wikipedia are generally more "Western" in their coverage and Asian languages more "global", with interesting exceptions. We suggest how both Wikipedia and the wider cultural sector can address this gap in content and thus give Wikipedia a truly global perspective on the visual arts.

Keywords: Wikipedia, knowledge equity, Wikimedia, open culture, visual arts, cultural bias 


\section{Contents}

Abstract 1

Contents 2

Introduction $\quad 4$

The impact of Wikipedia $\quad 4$

Cultural Bias $\quad 4$

The Visual Arts $\quad 5$

Paper Structure $\quad 6$

$\begin{array}{ll}\text { Methods } & 7\end{array}$

Definitions and Scope $\quad 7$

Identifying Western Artists $\quad 8$

Identifying Non-Western Artists $\quad 8$

Identifying Western Masterpieces 9

Identifying Non-Western Masterpieces $\quad 10$

$\begin{array}{ll}\text { Quantitative comparison } & 10\end{array}$

Results $\quad 12$

Quantitative Analysis $\quad 12$

Wikipedia articles $\quad 12$

Digital media files $\quad 12$

Database statements $\quad 13$

Differences across language versions $\quad 13$

Comparative Examples $\quad 15$

$\begin{array}{ll}\text { Discussion } & 18\end{array}$

Conclusions and Recommendations $\quad 20$

Recommendations for the cultural sector $\quad 20$

Recommendations for the Wikimedia contributor communities 21

Recommendations for Wikimedia organisations $\quad 22$

Limitations and Further Research $\quad 22$

Appendices $\quad 23$

100 Western Artists 23

100 Non-Western Artists 26

100 Western Masterpieces $\quad 30$

100 Non-Western Masterpieces $\quad 35$

Artist coverage ratios for some Wikipedias $\quad 41$ 
Examples of major national museums and art galleries outside the Western world (including indigenous art institutions in the West) 44

Select Bibliography $\quad 47$

$\begin{array}{ll}\text { Acknowledgements } & 48\end{array}$

Experts consulted $\quad 48$

$\begin{array}{ll}\text { Competing interests } & 48\end{array}$

$\begin{array}{ll}\text { Author roles } & 48\end{array}$

$\begin{array}{ll}\text { Works cited } & 50\end{array}$ 


\section{Introduction}

\section{The impact of Wikipedia}

Wikipedia is the world's leading website through which people learn about history and culture. It is the number one informational site on the web, and gets many times more use than museum websites. For example, the Metropolitan Museum of Art (the Met)'s images on Wikipedia get roughly 10 million hits per month versus 2 million per month on the Met's online catalogue (Maher and Tallon (2018)). Each day, there are 260 million views on English Wikipedia from about 70 million users. While it is difficult to know what proportion are for "cultural" articles, it is fair to say there is on English Wikipedia the equivalent of at least one Exposition Universelle (nine million attendance) every single day. The English Wikipedia is just one of nearly three hundred language versions, maintained by volunteer communities of differing sizes. The magnitude of this influence brings with it a responsibility of equal measure: to ensure its content is representational of the great diversity of communities and cultures that it engages and informs.

Wikipedia is part of the Wikimedia movement, which includes online platforms, volunteer communities, and charitable organisations, sharing the goals of open knowledge for all. In its current strategy ("Wikimedia Movement 2017 Strategy/ Direction" (2021)), the Wikimedia movement has explicitly committed to the goal of knowledge equity as one of two core principles: "As a social movement, we will focus our efforts on the knowledge and communities that have been left out by structures of power and privilege." This strategy shapes the grant-making activities of the organisations, and the partnerships sought. For example Wikimedia's GLAM-Wiki Initiative works with cultural institutions to share their resources openly ("GLAM" is an umbrella term for the cultural heritage sector, encompassing Galleries, Libraries, Archives, and Museums) ("GLAM-WIKI" (2021). This includes

Wikimedian-in-Residence programmes, in which experienced Wikipedian editors are commissioned by a cultural institution to support an open access culture in the host institution ("Wikimedian in residence" (2021)). Although this work is already being done, knowledge equity is such a big task that much more can potentially be done. In this paper we explore how Wikipedia could advance towards knowledge equity in the domain of the visual arts.

\section{Cultural Bias}

Various forms of bias on Wikipedia have already been described by research, and a focus of the activity for the Wikimedia organisations is activity to address these biases. Wikipedia's geographic bias and gender bias have their own literatures, so will be outside the scope of the present research. Here we focus specifically on cultural bias. That is, underrepresentation or misrepresentation of aspects of the 
cultures of the non-Western world. It has long been observed in the literature that the different language versions of Wikipedia reflect cultural biases of, and celebrate the "local heroes" of, their respective language communities (Callahan and Herring (2011), Kolbitsch and Maurer (2006)). For example, the biographies in European-language Wikipedias do not follow the pattern of world population but greatly emphasise the culture of Western Europe and the United States (Graham, Hale and Stephens (2011)).

Cultural biases existing on Wikipedia can generally be considered a reflection (both a cause and a consequence) of biases existing in the literature and more widely in society. These societal biases have a long and well-documented history, rooted in systems of hegemony and oppression like imperialism. Seminal works such as Edward Said's "Culture and Imperialism" have spotlighted how many of these biases persist in the postcolonial era. Globalization facilitated less of a proportionate cross-cultural exchange and more a spread of the predominant culture (that is, Western). The internet initially promised to make geography irrelevant, but algorithms have created new kinds of inequality in the amount of data about physical locations and its availability to different language communities (Graham and Zook (2013)).

Recent activism, such as Black Lives Matter and the debate over the holdings of European museums, has underlined the urgency of unearthing overlooked or oppressed histories and cultures. These questions are being raised in the most traditional cultural institutions as well as by online platforms such as Wikipedia.

\section{The Visual Arts}

Whereas many forms of bias relating to a specific culture - such as its music, language, literature, performing arts, history, fashion, food, philosophical ideas clearly exist, this paper pertains specifically to the visual arts. As per the scope of this paper, the culture under examination is the entire 'non-Western' world (a concept defined later).

A pro-Western cultural bias relating to the visual arts can be demonstrated with a superficial survey of visual-art-related lists on English Wikipedia, the largest language version. For example its "list of sculptors" is $99 \%$ Western, "list of painters by nationality" is around $75 \%$ European and its "list of contemporary visual artists" is $80 \%$ European. Moreover, many countries (even those with especially rich artistic traditions such as Libya and Mali) do not even have dedicated articles about their art in the same way as there exist exhaustive articles such as "Art of France" or "Art of Greece". This national bias is further evidenced by the "list of national museums" where non-Western national museums (even those among the most visited in the world e.g. Brazil) have relatively short, insufficient articles, often without collections galleries (something that is almost a given for most major Western museums). It is 
also indicated by the fact that despite there being many museums in the non-West dedicated to a single artist, the articles covering the "list of single artist museums" and "museums devoted to one artist" are $90 \%$ Western.

One could imagine a situation where Persian Wikipedia had a similar emphasis on Middle Eastern art and so on: in other words, where these imbalances in coverage were all due to the "local hero" effect. Instead, we think a larger bias is at play. Our hypothesis is that Wikipedia (taking all its language versions as a whole) has significant and systemic imbalances in the representation of non-Western visual arts, and that these can be identified and addressed. As such, the main objectives of this research are: to identify those areas in Wikipedia's coverage of the (visual) arts where there are significant imbalances according to culture, language and geography; to ascertain the scale and nature of these imbalances; to describe what a more equitable representation of visual arts on Wikipedia would look like; and finally to suggest strategic and practical ways towards that greater balance, building on the work already being done by the Wikipedia communities and organisations.

\section{Paper Structure}

To test the hypothesis concerning the representation of non-Western cultural content on Wikipedia, this paper will take both a quantitative and qualitative approach. A research methodology based on making comparisons of the coverage of Western artists and artworks vis-à-vis their non-Western counterparts will be employed.

- Identifying 100 leading Western artists, assessing the extent and quality of their coverage in English and other languages

- Identifying 100 leading non-Western artists of comparable calibre/stature assessing the extent and quality of their coverage in English and other languages

- Making a comparison and drawing out several case studies as examples

- Identifying 100 leading Western masterpieces - assessing the extent and quality of their coverage in English and other languages

- Identifying 100 leading non-Western masterpieces of comparable calibre/stature - assessing the extent and quality of their coverage in English and other languages

- Assessing the variation of imbalance according to the platform (Commons versus Wikipedia versions versus Wikidata) 


\section{Methods}

\section{Definitions and Scope}

What exactly are we classifying as 'visual art'? In theory, visual art can refer to a range of artistic expressions including conceptual art, installation art and contemporary art, but this paper will focus on the traditional art forms that have been practiced over the centuries and across the world and have often been referred to as 'fine art'. Yet what is considered 'fine art' too differs according to different cultures the hierarchy in the West has placed epic easel painting at the highest, whereas in the Islamic world calligraphy is among the highest, as are textiles and miniatures in Persia, calligraphic landscapes in China, and in Japan there is a special reverence for decorative and applied arts.

This study balances the need to be respectful to each of these hierarchies, whilst also standardising to some degree to allow for reasonable comparison. After careful consideration of these cultural sensitivities, it was decided that the paper largely focus on painting and sculpture but also include other media such as illuminated manuscripts, textiles and calligraphy. It does not include architectural features, although it must be noted that much artistry and craftsmanship - for example, the stained glass windows of European Cathedrals or the geometric tilework and calligraphic inscriptions in Samarkand, Bukhara and Alhambra - was recruited to towards the aims of aesthetic creativity. The study does not include architecture, ancient artifacts, manuscripts (unless with calligraphy and illumination of considerable merit), jewelry, furniture or fashion.

Many of the artists involved in these projects - particularly outside the West - remain anonymous.

The 'West' is a problematic term and concept, as it promotes the notion of a bipolar, dichotomic world. What is classified as non-Western culture is all culture originating and prevailing outside of Europe, Scandinavia, Russia and Eastern Europe and North America and Australasia, except for those cultures (now in the minority) indigenous to those lands such as aboriginal and Inuit. This is an extremely large group.

Is it fair to put Europe with a population of one sixth of the world against the rest? It would in theory be more apt to compare Europe with another continent such as Latin America or Africa. This should be an absurd exercise, but in fact the results show it is absurd for exactly the opposite reasons.

The time scope of art in this study is roughly 1000 years. There are many reasons for this. Firstly, this covers the emergence of the conventional East-West dichotomy, 
and therefore the "West and the rest" narrative that continues to this day. Secondly, this period comprises major cultural civilisations from across the world and therefore various artistic golden ages, which celebrated, commissioned, recorded and preserved the works of leading artists. Thirdly, this covers the era of the great European empires, which collectively governed the majority of the non-European world - important, as (especially) the last 500 years of European colonialism suppressed or looted many indigenous works from the colonies, the legacy of which is much of the knowledge imbalance that this paper seeks to highlight. Fourthly, before this period artworks were often considered artifacts (or sometimes in the Western case antiquities) rather than masterpieces produced by an individual artist, or even a guild or atelier. A typical demonstration of this might be the exhibition of the piece in a historical museum rather than a dedicated fine art gallery.

\section{Identifying Western Artists}

English Wikipedia has a system of "Vital Article" lists which define topics which are judged to have different levels of encyclopedic importance ("Wikipedia:Vital articles" (2020)). Level 1 contains ten articles (including "The arts"), Level 2 contains one hundred articles (including "Visual arts"), and so on. These lists are compiled irrespective of the quality of the existing articles. It is fair to the Wikipedia community to use a standard they have set themselves, so we took the Vital Article lists as a starting point.

The 10,000 topics at Vital Article Level 4, as of November 2020, included 78 Western artists; our shortlist began with these. The additional 22 artists were selected after consultation with the wide range of lists available in media articles and published books. "Top 100 artists" lists are common with regards to Western artists. In our choices we aimed to diversify a list dominated by painters from a few European countries, introducing women, decorative artists and Scandinavian artists.

\section{Identifying Non-Western Artists}

The same methodology for establishing the set of leading non-Western artists was simply impossible. For instance, only three leading non-Western artists have vital articles (Hokusai, Riviera and Kahlo). No single definitive list exists as a counterpart to the abundance of sources defining the Western canon. Therefore a mixed methodology was developed towards making a list of 100 artists that could credibly serve as a counterpart to our Western list.

One of the starting points was to consult the lists already available on Wikipedia. The 'list of African artists' and 'list of Chinese artists', for example, provided a sound basis for further investigation, as it is these lists - however inadequate - that we intend to amend and enrich as a result of the research. This initial compilation of non-Western artists was then cross-referenced against those listed through Google 
search's respective lists such as 'African artists' or 'Chinese artists'. As Wikipedia and Google lists of this sort are usually considered indicators of popularity, those appearing on both lists were shortlisted for further investigation.

Separately, a digital media search was conducted and a number of magazine articles for example 'Top African artists' or 'The Greatest Japanese sculptors' and other such rankings were consulted. Where names appeared frequently in different articles, those were shortlisted and again cross-referenced with existing lists. A high-level (though limited) literature review of books and articles was conducted to list the canon in each major region according to academic experts. These were again cross-referenced against existing lists with a view to shortlisting those artists that were both popular as well as critically acclaimed.

Another measure or 'marker' for artists deserving a place on this shortlist was whether they had attained official recognition through national and international awards, as well as receiving the highest national honours for their contribution to visual arts, as well as those considered 'national artists' or those appointed 'imperial court artists'. Some of these names overlapped with existing research whereas others required further validation. Much of this validation came from interviews with experts in the respective fields of art. These experts are listed in the Acknowledgements.

Finally we cut down the lists of Western and non-Western artists to make lists that were similar in terms of time period coverage and were diverse in multiple respects. It is important to note here that the resultant list (in the Appendix) is a representative and indicative sample, sufficient for this particular study to test the hypothesis and provide indicative results. It is not exhaustive and certainly not aimed at establishing a definitive 'top 100'. The latter would be outside the scope of this paper, and require extensive research and consultation, warranting a paper in its own right.

The English Wikipedia defines a topic as notable when it has significant coverage in at least three reliable sources. Language versions of Wikipedia differ somewhat in their notability standards. All the artists identified through the various forms of research can be considered notable, and therefore deserving of Wikipedia articles. For the purposes of this study, where the objective was to have a representative sample list of counterpart artists to those in Western culture, shortlisting through this process of verification suffices. Some names who created more than one masterpiece were also included.

\section{Identifying Western Masterpieces}

As with the Western artists, we used English Wikipedia's lists of Vital Articles as a starting point for our target list of masterpieces. Getting the relevant articles from Vital Articles Level 5 and filtering out some that were ancient or too recent gave us 
170 works. Wikidata allowed us to identify that 78 of these works had articles in Encyclopedia Britannica, which was an additional cue to notability. The longlist included many cases of multiple works by the same artist, so we cut this list down to 100 while preserving diversity by removing works by artists who were already included.

\section{Identifying Non-Western Masterpieces}

The process of shortlisting a representative set for leading non-Western masterpieces was different from all of the above, though there are some similarities with the process of researching non-Western artists.

This list was the most challenging to compile - firstly, this is because no such list currently exists, and secondly because substantial research into non-Western masterpieces would simply unveil too many options to shortlist from. Though Wikipedia and Google search unearthed some notable examples of non-Western masterpieces, this method was not as helpful as it was for researching non-Western artists.

So we began by including the most celebrated works listed as 'national treasures' by various non-Western countries, namely those that subscribed to our remit of visual art. In addition, highlights from National Museum and Galleries collections across Asia, Africa and Latin America were also long-listed as were those identified from a media review as artworks of symbolic significance or representing an important cultural movement. We added to this a select number of works from the non-West that broke sales records at major auction houses, as well as names appearing repeatedly through our literature review. The list was finalised after cross-referencing with scholarly experts and shortlisted to 100 based on the expert discretion of the authors of this paper.

\section{Quantitative comparison}

The finalised lists of Western and non-Western artists and masterpieces defined four content areas whose coverage we could explore both quantitatively and qualitatively. The Wikimedia family of sites allow users to build, remix and share open content about visual art in different modalities. We measured how three different platforms represent the topics on our Western and non-Western target lists.

On Wikipedia, there are narrative articles. On Wikimedia Commons, there are freely-licensed images and other digital media with associated metadata. The images are used to illustrate Wikipedia articles and other educational materials, and constitute an educational and research resource in their own right. On Wikidata, there are machine-readable statements (such as that Auguste Rodin was born in Paris) with attached citations. These statements can be extracted by custom queries 
and visualisations and are used in applications inside and outside Wikimedia. These include the "infoboxes" that give basic facts about a topic in a Wikipedia article or Commons category index. There are other Wikimedia platforms, but just these three - the most relevant to visual arts - are considered in this paper. Wikipedia exists in hundreds of different language versions, while Wikidata and Commons are each single, multilingual sites.

A Wikipedia article can be anything from a single line of text to a 20,000 word essay. A minimal Wikidata representation of an artist consists of a name, a one-line description, basic statements (e.g. this is a human being, of male gender, whose occupation is sculptor), and perhaps an authority file identifier. A more fully developed Wikidata representation will include dozens of biographical details including family relations, places of education and work, and identifiers in potentially hundreds of external sites and databases. So when measuring the representation of the topic, it is important to account for the size of the article or data item, not just its presence or absence.

The Wikimedia sites have APIs (Application Programming Interfaces) which allow external code to request specific information such as the length of an article ("API:Main page" (2021)). In the case of Wikidata, these can include sophisticated database queries. We wrote code that, via the APIs of Wikidata, Commons and the many different language versions of Wikipedia, extracted the quantitative information needed for our target lists. 


\section{Results}

\section{Quantitative Analysis}

\section{Wikipedia articles}

Wikidata queries provide all the Wikipedia articles about a given topic - in this case, articles about the artists and artworks in our lists. Our code then requested the byte length of each article from the relevant language version of Wikipedia. Byte-length is a fairer measure of the content of an article than character count. For example, characters in English take one byte each, in Hebrew two bytes each and in Chinese three or four bytes each.

It was discovered that there were five times as many articles about our Western artists (total 7,808$)$ as non-Western $(1,621)$ and sixteen times as many for Western masterpieces $(2,570)$ as for non-Western (165). The most-represented artist, Leonardo da Vinci, has articles in 222 language versions of Wikipedia. Taking article size into account, there is a little over seven times as much Wikipedia coverage of the Western artists (107 million bytes) as non-Western (15 million) and eighteen times as much of the Western masterpieces (25 million) as non-Western (1.4 million).

\section{[figure 1 goes here]}

[figure 2 goes here]

\section{Digital media files}

Files on Wikimedia Commons can be tagged with an artist's name for many reasons. They may be a depiction of that artist, a photograph of an art work, or a document relating to them. The connection can be more tenuous: photographs of places where the artist lived, or of places named after them. A Wikidata query provided us with the categories relating to our chosen artists. Categories can contain sub-categories, and so on iteratively, so to get total numbers of files we used the Commons API and, for a few especially large categories, the PetScan tool created by Magnus Manske (https://petscan.wmflabs.org/). There might be files related to a topic that exist on Commons but are not categorised appropriately, or where the category link exists but is not known to Wikidata, so our measure might underestimate the coverage of obscure topics, although we mitigated this by searching directly on Commons and adding a few links that were missing in Wikidata.

We found twenty-one times as many files for Western artists (total 185,509) as for non-Western (8,980 files). All of the Western artists had a category on Commons, compared to 84 of the non-Western. 


\section{[figure 3 goes here]}

\section{Database statements}

On Wikidata, all of our Western artists and masterpieces were already represented. Of the 100 non-Western artists, 99 already existed in Wikidata, along with 34 of the 100 non-Western masterpieces. Wikidata's query service allowed us to count the statements for each. We found just under four times as many statements about Western artists as non-Western artists, and nine times as many statements about Western as non-Western masterpieces.

\section{[figure 4 goes here]} [figure 5 goes here]

\section{Differences across language versions}

The language versions of Wikipedia have contributor communities that vary greatly in their size and where they are located. Thus they vary in the amount of text they have produced, and about what topics. For each pair of an artist and a language version of Wikipedia, our data have a byte count expressing the size of the artists' article in that language. By summing across each language, we can compare our matched lists, measuring the degree to which different Wikipedias prioritise the Western canon in the field of visual arts. Since we are comparing the coverage given to matched lists, our measure is not directly affected by the size of the Wikipedia itself.

Our measure is each Wikipedia's coverage of our Western artists, divided by its coverage of the non-Western artists. Thus, higher numbers mean a more Western focus and lower mean more global. The table below shows this ratio for 86 of the larger Wikipedias. Six of them give more coverage to our non-Western than to Western artists.

As expected, European languages tend to have higher ratios while Asian languages are lower. There are anomalies; Thai is the most Western in its coverage of visual arts, and English and Scots are among the most global. The ratio across all Wikipedias is, as we have seen above, just over 7 . So Japanese Wikipedia, with a ratio more than 8 , is more focused on the Western canon than the Wikipedias as a whole.

\begin{tabular}{|l|l|r|r|r|}
\hline Language & Language code & $\begin{array}{r}\text { Western } \\
\text { artists (bytes) }\end{array}$ & $\begin{array}{r}\text { Non-Western artists } \\
\text { (bytes) }\end{array}$ & Ratio \\
\hline Thai & th & 1577064 & 37777 & 41.75 \\
\hline Galician & $\mathrm{gl}$ & 1560347 & 106539 & 14.65 \\
\hline
\end{tabular}




\begin{tabular}{|c|c|c|c|c|}
\hline Italian & it & 3846109 & 279501 & 13.76 \\
\hline Serbian & sr & 1877184 & 147803 & 12.70 \\
\hline Polish & $\mathrm{pl}$ & 1856378 & 157538 & 11.78 \\
\hline Simple English & en-simple & 478046 & 43888 & 10.89 \\
\hline Hungarian & hu & 1553127 & 152783 & 10.17 \\
\hline Hebrew & he & 1243742 & 137012 & 9.08 \\
\hline Turkish & $\operatorname{tr}$ & 1130276 & 133821 & 8.45 \\
\hline Portuguese & pt & 1822828 & 216634 & 8.41 \\
\hline Japanese & ja & 2893884 & 344564 & 8.40 \\
\hline Czech & cs & 1685339 & 204217 & 8.25 \\
\hline German & de & 4513825 & 555219 & 8.13 \\
\hline Spanish & es & 4202760 & 517974 & 8.11 \\
\hline Dutch & $\mathrm{nl}$ & 1636039 & 228762 & 7.15 \\
\hline French & fr & 6235180 & 876287 & 7.12 \\
\hline Malayalam & $\mathrm{ml}$ & 1374045 & 205898 & 6.67 \\
\hline Catalan & ca & 2254534 & 341903 & 6.59 \\
\hline Welsh & cy & 391141 & 68955 & 5.67 \\
\hline Russian & ru & 5330034 & 958510 & 5.56 \\
\hline Vietnamese & vi & 1042035 & 194942 & 5.35 \\
\hline Chinese & $\mathrm{zh}$ & 1274771 & 242399 & 5.26 \\
\hline Arabic & ar & 1401071 & 267791 & 5.23 \\
\hline Ukrainian & uk & 2797317 & 614581 & 4.55 \\
\hline Armenian & hy & 2239028 & 530142 & 4.22 \\
\hline Persian & fa & 1634226 & 392738 & 4.16 \\
\hline English & en & 5927835 & 1494254 & 3.97 \\
\hline Indonesian & id & 565859 & 171585 & 3.30 \\
\hline Hindi & hi & 337095 & 121612 & 2.77 \\
\hline Punjabi & pa & 340529 & 177997 & 1.91 \\
\hline Bengali & bn & 598682 & 343743 & 1.74 \\
\hline Gujarati language & gu & 221480 & 165210 & 1.34 \\
\hline Urdu & ur & 65583 & 110819 & 0.59 \\
\hline
\end{tabular}

The full version of this table is given in an appendix. 


\section{Comparative Examples}

Having explored the size of the content gap, we now illustrate it with specific examples of artists, artworks and art movements.

The Sistine Chapel in the Vatican and the Sultan Ahmed Mosque (Blue Mosque) in Istanbul are two of the world's most visited places of worship - each having approximately 5 million visitors a year, making them comparable in terms of places of considerable interest to devotees and to tourists. Importantly, interest in them is not only because they are places of religious and historical significance, but also because the interiors of these places are considered to be of works of tremendous artistic merit. This is particularly the case with their ceilings. The ceiling of the Sistine Chapel was painted by the master Michelangelo in the early sixteenth century and is itself considered an iconic masterpiece in the history of Western art. It is composed of various Biblical stories painted in traditional Renaissance figurative style. The ceiling of the Blue Mosque was likewise painted by a master; though in this case the master calligrapher, Syed Kasim Gubari. Like Michelangelo, Gubari is considered one of the great masters in the history of his region/culture's art (in this case Ottoman/Islamic).

Whereas Michaelangelo is extensively represented on Wikipedia $(3,902,976$ bytes in 198 language versions), Gubari has minimal representation (short articles in four languages, totalling 8,772 bytes). Moreover, "Sistine Chapel ceiling" has an extensive Wikipedia article whereas "Blue Mosque ceiling" does not have an article or even a Wikidata entry.

\begin{tabular}{|l|l|l|}
\hline & Sistine Chapel ceiling & Blue Mosque ceiling \\
\hline Wikipedia & $\begin{array}{l}936,019 \text { bytes in } 25 \\
\text { languages }\end{array}$ & n/a \\
\hline $\begin{array}{l}\text { Wikimedia } \\
\text { Commons }\end{array}$ & 597 files & $\begin{array}{l}253 \text { files (Category: Interior } \\
\text { of Sultan Ahmed I Mosque) }\end{array}$ \\
\hline Wikidata & 52 statements & n/a \\
\hline
\end{tabular}

Su Shi, the 11th century Chinese artist whose painting broke the record for highest selling Asian artwork, was a polymath, also celebrated as a poet, engineer, litterateur, scientist and political figure. He is covered in 35 language versions of Wikipedia, whereas the Western polymath and comparably versatile artist Leonardo da Vinci is one of the most covered artists on Wikipedia, with articles in 222 languages totalling nearly five million bytes. 


\begin{tabular}{|l|l|l|}
\hline & Leonardo da Vinci & Su Shi \\
\hline Wikipedia & $\begin{array}{l}4,823,238 \text { bytes in } 222 \\
\text { languages }\end{array}$ & $\begin{array}{l}328,858 \text { bytes in } 35 \\
\text { languages }\end{array}$ \\
\hline $\begin{array}{l}\text { Wikimedia } \\
\text { Commons }\end{array}$ & 23,164 files & 267 files \\
\hline Wikidata & 376 statements & 120 statements \\
\hline
\end{tabular}

Likewise, comparably celebrated royal court portrait painters such as Hans Holbein (15th century England) and Mihr Ali (18th century Persia) have remarkably different Wikipedia coverage levels.

\begin{tabular}{|l|l|l|}
\hline & Hans Holbein & Mihr 'Ali \\
\hline Wikipedia & $\begin{array}{l}\text { 854,397 bytes in } 63 \\
\text { languages }\end{array}$ & 40,854 bytes in 6 languages \\
\hline $\begin{array}{l}\text { Wikimedia } \\
\text { Commons }\end{array}$ & 2,232 files & 21 files \\
\hline Wikidata & 205 statements & 21 statements \\
\hline
\end{tabular}

Beyond artists and artworks, another way of seeing the disproportionality in representation of the visual arts is by analyzing Western artistic movements vis-à-vis counterparts outside the West. For example the Pre-Raphaelite Brotherhood in 19th century England was a major movement which sought a return to traditional forms of Western art and comprised a number of notable artists, critics and patrons (such as Millais, Burne-Jones, Gabriel-Rossetti, Ruskin, Morris). It is extensively covered on Wikipedia, Commons and Wikidata. The Bengal School of Art likewise rejected modernism and sought a reversion to traditional forms and also included major artists, critics and patrons such as Bose, Tagore, and Kastghir. Its coverage on Wikipedia is minimal in comparison to that of the Pre-Raphaelite Brotherhood.

\begin{tabular}{|l|l|l|}
\hline & $\begin{array}{l}\text { Pre-Raphaelite } \\
\text { Brotherhood }\end{array}$ & Bengal School \\
\hline Wikipedia & $\begin{array}{l}876,061 \text { bytes in } 54 \\
\text { languages }\end{array}$ & $\begin{array}{l}31,148 \text { bytes in 3 languages } \\
\text { (English, French, Bengali) }\end{array}$ \\
\hline $\begin{array}{l}\text { Wikimedia } \\
\text { Commons }\end{array}$ & 10,233 files & 121 files \\
\hline
\end{tabular}




\begin{tabular}{|l|l|l|}
\hline Wikidata & 43 statements & 5 statements \\
\hline
\end{tabular}

Another suitable comparison might be the European post-impressionists and the Japanese Nihonga movement.

\begin{tabular}{|l|l|l|}
\hline & Post-Impressionism & Nihonga \\
\hline Wikipedia & $\begin{array}{l}\text { 407,327 bytes in } 65 \\
\text { languages }\end{array}$ & $\begin{array}{l}136,979 \text { bytes in } 16 \\
\text { languages }\end{array}$ \\
\hline $\begin{array}{l}\text { Wikimedia } \\
\text { Commons }\end{array}$ & 31,041 files & 2,322 files \\
\hline Wikidata & 42 statements & 13 statements \\
\hline
\end{tabular}




\section{Discussion}

We have replicated the common finding of a "local hero" effect, with European artists given higher priority in European-language Wikipedias, but that is not the most salient result. Looking at Wikipedia as a whole, and at the multilingual sites Wikidata and Wikimedia Commons, we found large differences in their relative coverage of our Western and non-Western artists: ratios of 7, 4 and 21 respectively. We showed earlier that an examination of English Wikipedia shows a strong emphasis on Western rather than non-Western art; it turns out that English is one of the least biased major Wikipedias in this respect.

By our quantitative measure, Wikidata has much less Western bias than Wikipedia collectively, and Wikimedia Commons has much more. The differences in ratio for different platforms can be understood in terms of how each platform sets floors or ceilings on the size of representations. Wikimedia Commons has no upper limit on the number of digital files that can be tagged with a given topic. While there is no technical upper limit on the statements about a topic in Wikidata, there are only a certain number of properties that can be represented in that database. Wikipedia's style guides put upper limits on the length of articles - usually that they should not exceed 100,000 bytes - although these can vary between languages and are not rigidly enforced.

That English Wikipedia is relatively balanced compared to other language versions (but still giving a small fraction of coverage to the non-Western artists) might be due to the great deal of scholarship being published in English and research done in English-language institutions. It might reflect the activity of Wikimedia chapters and groups that have built partnerships with cultural organisations. It could conceivably be a ceiling effect from it being the largest Wikipedia. If the Western canon is already as extensively documented as it can be, an English Wikipedia contributor wanting to create a new article about an artist is more likely to look to non-Western topics.

The Wikipedia versions with the largest coverage of non-Western artists are English, Russian and French. This suggests one interim way to address the imbalance and make other language Wikipedias more global may be to translate articles from these European languages to other languages. This would help improve the pro-European emphasis of Wikipedia as a whole, although it would mean that the articles are drawn primarily from sources in European languages. This would be a step in the right direction, but not a solution to the problem of knowledge inequity due to systems of power and privilege, for which we suggest bolder action later on.

We did a follow-up analysis focusing on coverage of the Arabic and Persian artists and masterpieces. Summing the coverage of these topics, excluding those languages whose total coverage is less than 100,000 bytes, gives us the following table: 


\begin{tabular}{|l|l|l|}
\hline Lang code & Language & $\begin{array}{l}\text { Total article size } \\
\text { (bytes) }\end{array}$ \\
\hline fa & Persian & 332,648 \\
\hline en & English & 326,158 \\
\hline cy & Welsh & 234,738 \\
\hline ru & Russian & 229,462 \\
\hline ar & Arabic & 169,081 \\
\hline fr & French & 155,712 \\
\hline de & German & 128,296 \\
\hline es & Spanish & 127,264 \\
\hline
\end{tabular}

This underlines that, although Russian (the seventh largest Wikipedia) gives a small proportion of its coverage to our non-Western art when compared to Western (a ratio of 5.6), its sheer size means that it has more content about Arabic and Persian visual arts than Arabic Wikipedia does. Hence it would help Wikipedia become more global, by our blunt quantitative criterion, if there were translations of articles from Russian or English to Arabic.

Welsh Wikipedia has deployed a sophisticated process for bulk-creating articles from textual templates and facts from Wikidata, which accounts for its extensive coverage despite having a relatively small community of volunteer contributors. While articles created this way lack the narrative nuance of a human-written article, they give basic facts about a topic and have automatically-generated citations. This demonstrates another way Wikipedias can build their coverage of an under-represented topic. 


\section{Conclusions and Recommendations}

\section{Recommendations for the cultural sector}

The representation of a topic on the Wikimedia sites depends on multiple factors. Suitable sources need to be available; suitably-licensed images need to be uploaded, or put where Wikimedia volunteers can easily access them; and the writing, reviewing, and improvement of a Wikipedia article take effort. Organisations such as museums, galleries, and publishers can thus help extend the representation of non-Western art in various ways.

- Paywalled publications are a significant barrier for most Wikipedia contributors, so it is helpful if existing research can be put on open access.

- One way to kick-start Wikipedia articles is by repurposing existing text publications. These need to match Wikipedia's purpose, by summarising mainstream scholarship on a topic rather than reporting new research or synthesis, and they need to be freely licensed. Such articles can be pasted into Wikipedia and given an attribution template which credits and links the original source ("Help:Adding open license text to Wikipedia" (2021)).

- Wikipedia is a summary of reliable sources, and increasing the range of sources about non-Western art would serve the knowledge equity goal of "sharing knowledge [...] left out by structures of power and privilege". The implicit knowledge of experts was crucial to our research, and more of this implicit knowledge could be made explicit by being published.

- Image collections, whether out of copyright or freely licensed, can be shared by direct upload to Wikimedia Commons or at least placed openly online where Wikimedia volunteers can access them. There are tools and processes for doing this in bulk and for making sure the files have suitable metadata ("Commons:Guide to content partnerships" (2021)).

- By employing a Wikimedian In Residence, an institution makes the best use of Wikimedia platforms to ensure the visibility of its collections. An experienced Wikimedia contributor will be able to make images findable, engage a wider community and report on metrics of success. Wikimedia's local chapters can help institutions recruit suitable Wikimedians ("Wikimedian in residence" (2021)).

- Cultural institutions can also provide identifiers and basic biographical information for artists and works, which can be linked from Wikidata and used to establish notability.

- The Wikipedia Library (Orlowitz (2018)) is an initiative in which publishers of paywalled scholarship can give temporary access to selected Wikipedia 
contributors, helping them create and improve articles with citations to those scholarly sources. Publishers of relevant material can consider joining this if open access is not an option. Oxford Art Online, published by the Oxford University Press, is a relevant source available through this method, which more publishers could adopt.

- The OpenGLAM Principles (OpenGLAM Working Group (2011) set out how a cultural institution can use its intellectual property policy and technical infrastructure to promote the widest engagement with its collections. The principles, currently being revised, capture actions that would be helpful to the Wikimedia platforms as well as the wider community.

\section{Recommendations for the Wikimedia contributor communities}

Wikipedia and Wikimedia volunteer contributors can take action straight away to reduce the content gaps described in this paper.

- An outstanding example of work to reduce a content gap on Wikipedia is the Women In Red project ("Wikipedia:WikiProject Women in Red" (2021)). This addresses the gender content gap by using Wikidata and other sources to build "redlists": lists of notable women who do not yet have a Wikipedia article and whose links are therefore red. Volunteers can choose an article to create, turning the link from red to blue. We propose that there should be similar projects for the gaps in representation of the visual arts. The Wikidata identifiers and other information in our appendices can be used to make redlists.

- The community should consider adding artists and masterpieces from our non-Western lists to the Vital Article lists on English Wikipedia, and any counterparts on other language versions.

- Since 2015 Wikipedia has had a Content Translation tool which prepares a machine-translated version of an article which a human user can correct and publish (Dolmaya (2017)). We have seen that English, French and Russian Wikipedias have a relatively large volume of coverage of non-Western art, so translation of those articles into more languages would improve the balance.

- A crucial supply of Commons images comes from photographs of out-of-copyright works that museum visitors have taken and then uploaded. For museums that do not have a formal programme of digitisation, this informal digitisation is an option for creating digital content. It requires the institution to allow, even encourage, visitors to take photographs as part of their engagement during the visit. 


\section{Recommendations for Wikimedia organisations}

Addressing knowledge gaps is already a main focus of the activity of the Wikimedia organisations (the San Francisco-based Wikimedia Foundation and the national and thematic Wikimedia Chapters). This takes the form of supporting or enabling community activities described in the previous section; funding dedicated research, software, or outreach; or building partnerships with other organisations ("Wikimedia Movement Strategy Recommendations" (2021)).

The list of existing cultural partnerships shows that Wikimedia has been successful in Europe and North American in building cultural partnerships with major institutions such as the Metropolitan Museum of Art and the British Library. There are many national institutions in the rest of the world that have not had any kind of partnership ("GLAM/Repository" (2021)). When looking on Commons for partnerships that had shared Islamic calligraphy, we found the Met, the Cleveland Museum of Art, the Library of Congress, Los Angeles County Museum of Art, and the National Library of Israel. So the material Wikimedians are working with to document Islamic art is coming mostly from the United States and not from institutions in the Islamic world. To address the gap described in this paper, the Wikimedia organisations should seek partnerships with national as well as grassroots cultural institutions across Asia, Africa, and Latin America as well as indigenous communities across North America and Oceania. We provide a list of relevant institutions in an Appendix.

\section{Limitations and Further Research}

Further subdivisions of the categories of Western and non-Western art and artists offer additional research questions that could be investigated. For example, examining gender parity in the history of Western art vis-à-vis the history of non-Western art in Wikipedia was outside the scope of this study, but clearly emerged as an important and necessary area of further research. Also related specifically to representation on Wikipedia, investigating the extent to which disproportionality in such content related to racial, ethnic, geographical, cultural, religious disproportionality in editors and readers would also be important.

Perhaps more indirectly related to representation on Wikimedia, investigating people's general knowledge of non-Western art history and exposing the bias or ignorance even among those considered to be 'cultured' or reasonably knowledgeable about art history (such as students and scholars) would be helpful in explaining how this is reflected on Wikipedia. 


\section{Appendices}

\section{Western Artists}

\begin{tabular}{|c|c|c|c|}
\hline Century & Artist & Nationality & Vital level \\
\hline 13 & Giotto & Italy & 4 \\
\hline 14 & Donatello & Republic of Florence & 4 \\
\hline 14 & Jan van Eyck & Southern Netherlands & 4 \\
\hline 15 & Masaccio & Italy & 4 \\
\hline 15 & Filippo Lippi & Republic of Florence & 5 \\
\hline 15 & Giovanni Bellini & Republic of Venice & 5 \\
\hline 15 & Sandro Botticelli & Italy & 4 \\
\hline 15 & Hieronymus Bosch & Southern Netherlands & 4 \\
\hline 15 & Leonardo da Vinci & Republic of Florence & 3 \\
\hline 15 & Albrecht Dürer & Duchy of Bavaria & 4 \\
\hline 15 & Michelangelo & Republic of Florence & 3 \\
\hline 15 & Raphael & Italy & 4 \\
\hline 15 & Titian & Republic of Venice & 4 \\
\hline 15 & $\begin{array}{l}\text { Hans Holbein the } \\
\text { Younger }\end{array}$ & Germany & 4 \\
\hline 16 & Pieter Bruegel the Elder & Duchy of Brabant & 4 \\
\hline 16 & El Greco & Spain & 4 \\
\hline 16 & Caravaggio & Duchy of Milan & 4 \\
\hline 16 & Peter Paul Rubens & Spanish Netherlands & 4 \\
\hline 16 & Artemisia Gentileschi & Italy & 4 \\
\hline 16 & Nicolas Poussin & France & 4 \\
\hline 16 & Francisco de Zurbarán & Spain & 5 \\
\hline 16 & Gian Lorenzo Bernini & Italy & 4 \\
\hline 16 & Anthony Van Dyck & Southern Netherlands & 5 \\
\hline 16 & Diego Velázquez & Spain & 4 \\
\hline 17 & Claude Lorrain & Duchy of Lorraine & 5 \\
\hline 17 & Rembrandt & Dutch Republic & 3 \\
\hline
\end{tabular}




\begin{tabular}{|c|c|c|c|}
\hline 17 & Johannes Vermeer & Dutch Republic & 4 \\
\hline 17 & Canaletto & Republic of Venice & 5 \\
\hline 17 & William Hogarth & United Kingdom & 4 \\
\hline 18 & Johan Zoffany & Germany & - \\
\hline 18 & Francisco Goya & Spain & 4 \\
\hline 18 & Jacques-Louis David & France & 4 \\
\hline 18 & William Blake & $\begin{array}{l}\text { United Kingdom of Great } \\
\text { Britain and Ireland }\end{array}$ & 4 \\
\hline 18 & Caspar David Friedrich & Germany & 4 \\
\hline 18 & J. M. W. Turner & Great Britain & 4 \\
\hline 18 & John Constable & Great Britain & 4 \\
\hline 18 & $\begin{array}{c}\text { Jean-Auguste-Dominique } \\
\text { Ingres }\end{array}$ & France & 4 \\
\hline 18 & Eugène Delacroix & France & 4 \\
\hline 19 & Christen Købke & Denmark & - \\
\hline 19 & Gustave Courbet & France & 4 \\
\hline 19 & Camille Pissarro & France & 4 \\
\hline 19 & Édouard Manet & France & 4 \\
\hline 19 & William Morris & $\begin{array}{l}\text { United Kingdom of Great } \\
\text { Britain and Ireland }\end{array}$ & 5 \\
\hline 19 & $\begin{array}{c}\text { James Abbott McNeill } \\
\text { Whistler }\end{array}$ & United States of America & 4 \\
\hline 19 & Edgar Degas & France & 4 \\
\hline 19 & Paul Cézanne & France & 4 \\
\hline 19 & Auguste Rodin & France & 4 \\
\hline 19 & Claude Monet & France & 3 \\
\hline 19 & Pierre-Auguste Renoir & France & 4 \\
\hline 19 & Henri Rousseau & France & 4 \\
\hline 19 & Ilya Repin & Russian Empire & 4 \\
\hline 19 & Peter Carl Fabergé & Russian Empire & 5 \\
\hline 19 & Paul Gauguin & France & 4 \\
\hline 19 & Vincent van Gogh & Netherlands & 3 \\
\hline 19 & John Singer Sargent & United States of America & 4 \\
\hline 19 & Georges Seurat & France & 4 \\
\hline
\end{tabular}




\begin{tabular}{|c|c|c|c|}
\hline 19 & Edvard Munch & Norway & 4 \\
\hline 19 & $\begin{array}{l}\text { Henri de } \\
\text { Toulouse-Lautrec }\end{array}$ & Second French Empire & 4 \\
\hline 19 & Akseli Gallen-Kallela & Finland & - \\
\hline 19 & Wassily Kandinsky & Russian Empire & 4 \\
\hline 19 & Henri Matisse & France & 4 \\
\hline 19 & Piet Mondrian & $\begin{array}{l}\text { Kingdom of the } \\
\text { Netherlands }\end{array}$ & 4 \\
\hline 19 & Aubrey Beardsley & $\begin{array}{l}\text { United Kingdom of Great } \\
\text { Britain and Ireland }\end{array}$ & 4 \\
\hline 19 & Nicholas Roerich & Russian Empire & 5 \\
\hline 19 & Constantin Brâncuși & France & 4 \\
\hline 19 & Kazimir Malevich & Russian Empire & 4 \\
\hline 19 & Paul Klee & German Reich & 4 \\
\hline 19 & Franz Marc & German Empire & 4 \\
\hline 19 & Jacob Epstein & United States of America & - \\
\hline 19 & Pablo Picasso & Spain & 3 \\
\hline 19 & Edward Hopper & United States of America & 4 \\
\hline 19 & Marc Chagall & France & 4 \\
\hline 19 & Marcel Duchamp & France & 4 \\
\hline 19 & L. S. Lowry & United Kingdom & - \\
\hline 19 & Georgia O'Keeffe & United States of America & 4 \\
\hline 19 & Jean Cocteau & France & 4 \\
\hline 19 & Max Ernst & Germany & 4 \\
\hline 19 & Joan Miró & Spain & 4 \\
\hline 19 & Norman Rockwell & United States of America & 4 \\
\hline 19 & M. C. Escher & $\begin{array}{l}\text { Kingdom of the } \\
\text { Netherlands }\end{array}$ & 4 \\
\hline 19 & Henry Moore & United Kingdom & 4 \\
\hline 19 & René Magritte & Belgium & 4 \\
\hline 19 & Mary Cassatt & United States of America & 5 \\
\hline 19 & Juan Gris & Spain & 5 \\
\hline 19 & $\begin{array}{l}\text { Pre-Raphaelite } \\
\text { Brotherhood }\end{array}$ & $\begin{array}{c}\text { United Kingdom of Great } \\
\text { Britain and Ireland }\end{array}$ & 4 \\
\hline
\end{tabular}




\begin{tabular}{|r|c|r|r|}
\hline 20 & Alberto Giacometti & Switzerland & 4 \\
\hline 20 & Barbara Hepworth & United Kingdom & 5 \\
\hline 20 & Willem de Kooning & United States of America & 5 \\
\hline 20 & Salvador Dalí & Spain & 4 \\
\hline 20 & Francis Bacon & Ireland & 4 \\
\hline 20 & Jackson Pollock & United States of America & 4 \\
\hline 20 & Joseph Beuys & Germany & 5 \\
\hline 20 & Lucian Freud & United Kingdom & 4 \\
\hline 20 & Roy Lichtenstein & United States of America & 4 \\
\hline 20 & Andy Warhol & United States of America & 5 \\
\hline 20 & Gerhard Richter & Germany & 5 \\
\hline 20 & David Hockney & England & 5 \\
\hline 20 & Anthony Gormley & United Kingdom & 5 \\
\hline 20 & Jean-Michel Basquiat & United States of America & 5 \\
\hline 20 & Banks & United Kingdom & 5 \\
\hline & & & 5 \\
\hline
\end{tabular}

\section{Non-Western Artists}

\begin{tabular}{|c|c|c|c|}
\hline $\begin{array}{c}\text { Date } \\
\text { of } \\
\text { Birth }\end{array}$ & Name & Nationality & Medium \\
\hline 1036 & Wang Shen & Chinese & Painting, Calligraphy \\
\hline 1037 & Su Shi & Chinese & Painting, Calligraphy \\
\hline 1050 & Li Tang & Chinese & Painting \\
\hline 1085 & Zhang Zeduan & Chinese & Painting \\
\hline 1142 & Fujiwara no Takanobu & Japanese & Painting \\
\hline 1150 & Unkei & Japanese & Sculpture \\
\hline 1160 & Ma Yuan & Chinese & Painting \\
\hline 1195 & Xia Gui & Chinese & Painting \\
\hline
\end{tabular}




\begin{tabular}{|c|c|c|c|}
\hline 1200 & Chen Rong & Chinese & Painting \\
\hline 1242 & Yaqut Al Mustasimi & Turkish/Arab & Islamic calligraphy \\
\hline 1254 & Ren Renfa & Chinese & Painting, Calligraphy \\
\hline 1254 & Zhao Mengfu & Chinese & Painting, Calligraphy \\
\hline 1269 & Huang Gongwang & Chinese & Painting \\
\hline 1280 & Wu Zhen & Chinese & Painting \\
\hline 1301 & Ni Zan & Chinese & Painting \\
\hline 1308 & Wang Meng & Chinese & Painting \\
\hline 1414 & Tenshō Shūbun & Japanese & Painting \\
\hline 1417 & Gang Hui-an & Korean & Painting, Calligraphy \\
\hline 1436 & Sheikh Hamdullah & Turkish (Ottoman) & Islamic calligraphy \\
\hline 1450 & Kamāl ud-Dīn Behzād & Persian & Painting \\
\hline $\begin{array}{c}\text { 15th } \\
\text { Century }\end{array}$ & Sultan Muhammad & Persian & Painting \\
\hline 1510 & Mir Sayyid Ali & Persian & Painting \\
\hline 1556 & Basawan & Indian & Painting \\
\hline 1560 & Daswanth & Indian & Painting \\
\hline 1564 & Xue Susu & Chinese & Painting \\
\hline 1565 & Reza Abbasi & Persian & Painting \\
\hline 1570 & Amanat Khan Shirazi & Iranian & Calligraphy \\
\hline 1573 & Wu Bin & Chinese & Painting \\
\hline 1578 & Iwasa Matabei & Japanese & Painting \\
\hline 1595 & Govardhan & Indian & Painting \\
\hline 1598 & Chen Hongshou & Chinese & Painting \\
\hline $\begin{array}{c}\text { 16th } \\
\text { Century }\end{array}$ & Abd al-Samad & Persian & Painting \\
\hline 1626 & Zhu Da (Bada Shanren) & Chinese & Painting, Calligraphy \\
\hline 1635 & Zanabazar & Mongolian & Painting \\
\hline $\begin{array}{c}\text { 17th } \\
\text { Century }\end{array}$ & Seyyid Kasim Gubari & Turkish (Ottoman) & Calligraphy \\
\hline $\begin{array}{c}\text { 17th } \\
\text { Century }\end{array}$ & Abdulcelil Levni & Turkish (Ottoman) & Painting \\
\hline $\begin{array}{c}17 \text { th } \\
\text { century }\end{array}$ & Bishandas & Indian & Painting \\
\hline
\end{tabular}




\begin{tabular}{|c|c|c|c|}
\hline $\begin{array}{l}\text { 17th } \\
\text { century }\end{array}$ & Bichitr & Indian & Painting \\
\hline $\begin{array}{l}\text { 18th } \\
\text { Century }\end{array}$ & Mihr 'Ali & Persian & Painting \\
\hline 1807 & Shibata Zeshin & Japanese & Painting \\
\hline 1811 & Raden Saleh & Indonesian & Painting \\
\hline 1842 & Osman Hamdi Bey & Turkish (Ottoman) & Painting \\
\hline 1848 & Kamal-ÖI-Molk & Iranian & Painting \\
\hline 1848 & Raja Ravi Varma & Indian & Painting \\
\hline 1861 & Rabindranath Tagore & Indian & Painting \\
\hline 1864 & Qi Baishi & Chinese & Painting \\
\hline 1871 & Abanindranath Tagore & Indian & Painting \\
\hline 1874 & Joaquín Torres-García & Uruguayan-Spanish & $\begin{array}{l}\text { Painting, Sculpture, } \\
\text { Illustration }\end{array}$ \\
\hline 1882 & Nandalal Bose & Indian & Painting \\
\hline 1883 & José Clemente Orozco & Mexican & Painting, Muralism \\
\hline 1886 & Tarsila do Amaral & Brazilian & Painting \\
\hline 1886 & Diego Rivera & Mexican & Painting \\
\hline 1889 & Anita Malfatti & Brazilian & Painting \\
\hline 1891 & John Dunkley & Jamaican & Painting \\
\hline 1894 & Hossein Behzad & Iranian & Painting \\
\hline 1894 & Irma Stern & $\begin{array}{l}\text { South African } \\
\text { (German-Jewish) }\end{array}$ & Painting \\
\hline 1895 & Pan Yuliang & Chinese & Painting \\
\hline 1897 & Abdul Rahman Chughtai & Pakistani & Painting \\
\hline 1897 & Mahmoud Said (Sa'id) & Egyptian & Painting \\
\hline 1899 & Rufino Tamayo & Mexican & $\begin{array}{c}\text { Painting, Printmaking, } \\
\text { Lithography, Drawing, } \\
\text { Etching }\end{array}$ \\
\hline 1900 & Edna Manley & Jamaican & $\begin{array}{c}\text { Sculpture (also known } \\
\text { for painting and } \\
\text { drawing) }\end{array}$ \\
\hline 1902 & Wifredo Lam & Cuban & Painting \\
\hline 1902 & Albert Namatjira & Aboriginal Australian & Painting \\
\hline
\end{tabular}




\begin{tabular}{|c|c|c|c|}
\hline 1904 & Abilkhan Kasteev & Kazakhstani & Painting \\
\hline 1907 & Frida Kahlo & Mexican & Painting \\
\hline 1907 & Sudhir Khastgir & Indian & Painting \\
\hline 1910 & Emily Kame Kngwarreye & Aboriginal Australian & Painting \\
\hline 1910 & Tran Van Can & Vietnamese & Painting \\
\hline 1911 & Roberto Matta & Chilean & Painting \\
\hline 1912 & George Pemba & South African & Painting \\
\hline 1913 & Gerard Sokoto & South African & Painting \\
\hline 1913 & Amrita Sher Gil & Hungarian-Indian & Painting \\
\hline 1914 & Allan Houser & Chiricahua Apache & $\begin{array}{l}\text { Sculpture, Painting, } \\
\text { Drawing, Murals }\end{array}$ \\
\hline 1914 & Zainul Abedin & Bangladeshi & Painting, Drawing \\
\hline 1914 & Anita Magsaysay-Ho & Filipino & Painting \\
\hline 1915 & M. F. Husain & Indian & Painting \\
\hline 1916 & Pudlo Pudlat & Canadian Inuit & Printmaking, Drawing \\
\hline 1917 & Ben Enwonwu & Nigerian & Painting, Sculpture \\
\hline 1918 & Luis Nishizawa & Japanese-Mexican & Painting, Ceramics \\
\hline 1918 & Hatem El Mekki & Tunisian & Painting \\
\hline 1919 & Rodrigo Arenas Betancort & Colombian & Sculpture \\
\hline 1919 & Daphne Odjig & $\begin{array}{l}\text { Odawa-Potawatomi-E } \\
\text { nglish (Canadian) }\end{array}$ & Painting \\
\hline 1919 & Wu Guanzhong & Chinese & Painting \\
\hline 1919 & Tahia Halim & Egyptian & Painting \\
\hline 1919 & Jawad Saleem & Iraqi-Turkish & Painting, Sculpture \\
\hline 1922 & Abdulmejid II & Turkish (Ottoman) & Painting \\
\hline 1922 & Fateh Moudarres & Syrian & Painting, Drawing \\
\hline 1923 & Sadequain & Pakistani & Calligraphy, Painting \\
\hline 1925 & Abd al-Hadi El-Gazzar & Egyptian & Painting \\
\hline 1927 & Kenojuak Ashevak & Inuit & $\begin{array}{c}\text { Soapstone carving, } \\
\text { Drawing, Etching, } \\
\text { Stone-cut, Printmaking }\end{array}$ \\
\hline 1928 & Mokarrameh Ghanbari & Iranian & Painting \\
\hline 1930 & Ibrahim El-Salahi & Sudanese & Painting \\
\hline
\end{tabular}




\begin{tabular}{|r|c|c|c|}
\hline 1930 & Napoleon Abueva & Filipino & Sculpture \\
1932 & Afewerk Tekle & Ethiopian & Painting \\
\hline 1932 & Clifford Possum Tjapaltjarri & Aboriginal Australian & Painting \\
\hline 1932 & Fernando Botero & Colombian & Painting, Sculpture \\
1933 & Uche Okeke & Nigerian & Drawing \\
1935 & Papa lbra Tall & Senegalese & $\begin{array}{c}\text { Tapestry weaving, } \\
\text { Painting, and } \\
\text { illustrating }\end{array}$ \\
\hline 1936 & Malangatana Ngwenya & Mozambican & Painting \\
\hline 1937 & Skunder Boghossian & Ethiopian-Armenian & Painting \\
\hline
\end{tabular}

\section{Western Masterpieces}

\begin{tabular}{|c|c|c|c|}
\hline $\begin{array}{l}\text { Date of } \\
\text { creation }\end{array}$ & Title or common name & Description in Wikidata & $\begin{array}{l}\text { Vital } \\
\text { level }\end{array}$ \\
\hline 1070 & Bayeux Tapestry & $\begin{array}{l}\text { embroidered tapestry depicting } \\
\text { the Norman invasion of England }\end{array}$ & 4 \\
\hline 1480 & The Birth of Venus & painting by Sandro Botticelli & 4 \\
\hline 1490 & $\begin{array}{c}\text { The Garden of Earthly } \\
\text { Delights }\end{array}$ & $\begin{array}{c}\text { Medieval triptych by Hieronymus } \\
\text { Bosch }\end{array}$ & 4 \\
\hline 1490 & The Last Supper (Leonardo) & $\begin{array}{l}\text { mural painting by Leonardo da } \\
\text { Vinci }\end{array}$ & 4 \\
\hline 1597 & Pietà (Michelangelo) & sculpture by Michelangelo & 4 \\
\hline 1642 & The Night Watch & 1642 painting by Rembrandt & 4 \\
\hline 1789 & $\begin{array}{c}\text { Songs of Innocence and of } \\
\text { Experience }\end{array}$ & $\begin{array}{c}\text { illuminated book by William } \\
\text { Blake }\end{array}$ & 4 \\
\hline 1863 & Le Déjeuner sur l'herbe & painting by Édouard Manet & 4 \\
\hline 1882 & The Thinker & $\begin{array}{l}\text { type of sculpture by Auguste } \\
\text { Rodin }\end{array}$ & 4 \\
\hline 1889 & The Starry Night & painting by Vincent van Gogh & 4 \\
\hline 1895 & The Scream & $\begin{array}{l}\text { group of paintings by Edvard } \\
\text { Munch }\end{array}$ & 4 \\
\hline
\end{tabular}




\begin{tabular}{|c|c|c|c|}
\hline 1931 & The Persistence of Memory & painting by Salvador Dali & 4 \\
\hline 1937 & Guernica (Picasso) & oil painting by Pablo Picasso & 4 \\
\hline 1942 & Nighthawks (painting) & $\begin{array}{c}1942 \text { oil on canvas painting by } \\
\text { Edward Hopper }\end{array}$ & 4 \\
\hline 1434 & Arnolfini Portrait & 1434 painting by Jan van Eyck & 4 \\
\hline 1914 & Water Lilies (Monet series) & $\begin{array}{l}\text { series of approximately } 250 \\
\text { paintings by Claude Monet }\end{array}$ & 4 \\
\hline 1425 & $\begin{array}{l}\text { The Tribute Money } \\
\text { (Masaccio) }\end{array}$ & fresco by Masaccio & 5 \\
\hline 1432 & Ghent Altarpiece & $\begin{array}{l}\text { polyptych by Hubert van Eyck } \\
\text { and Jan van Eyck }\end{array}$ & 5 \\
\hline 1445 & David (Donatello) & bronze statue by Donatello & 5 \\
\hline 1500 & David (Michelangelo) & statue by Michelangelo & 5 \\
\hline 1501 & $\begin{array}{c}\text { Triptych of the Temptation of } \\
\text { St. Anthony }\end{array}$ & $\begin{array}{c}\text { triptych by Hieronymus Bosch, } \\
\text { Lisbon }\end{array}$ & 5 \\
\hline 1503 & Mona Lisa & oil painting by Leonardo da Vinci & 5 \\
\hline 1509 & Sistine Chapel ceiling & $\begin{array}{l}\text { painted ceiling of the Sistine } \\
\text { Chapel in Vatican City }\end{array}$ & 5 \\
\hline 1512 & The School of Athens & fresco by Raphael & 5 \\
\hline 1523 & Bacchus and Ariadne & painting by Titian & 5 \\
\hline 1535 & $\begin{array}{c}\text { The Burial of the Count of } \\
\text { Orgaz }\end{array}$ & painting by El Greco & 5 \\
\hline 1539 & $\begin{array}{l}\text { The Last Judgement } \\
\text { (Michelangelo) }\end{array}$ & $\begin{array}{l}\text { Sistine Chapel fresco by } \\
\text { Michelangelo Buonarroti }\end{array}$ & 5 \\
\hline 1563 & The Tower of Babel (Bruegel) & $\begin{array}{l}\text { three paintings by Pieter Bruegel } \\
\text { the Elder }\end{array}$ & 5 \\
\hline 1565 & The Hunters in the Snow & $\begin{array}{c}\text { painting by Pieter Brueghel the } \\
\text { Elder }\end{array}$ & 5 \\
\hline 1595 & The Musicians (Caravaggio) & painting by Caravaggio & 5 \\
\hline 1610 & $\begin{array}{l}\text { The Elevation of the Cross } \\
\text { (Rubens) }\end{array}$ & $\begin{array}{l}\text { triptych by Peter Paul Rubens in } \\
\text { Cathedral of Our Lady, Antwerp }\end{array}$ & 5 \\
\hline 1656 & Las Meninas & painting by Diego Velazquez & 5 \\
\hline 1665 & Girl with a Pearl Earring & painting by Johannes Vermeer & 5 \\
\hline 1732 & A Harlot's Progress & $\begin{array}{l}\text { series of paintings and } \\
\text { engravings by William Hogarth }\end{array}$ & 5 \\
\hline
\end{tabular}




\begin{tabular}{|c|c|c|c|}
\hline 1750 & Mr and Mrs Andrews & $\begin{array}{l}\text { painting by Thomas } \\
\text { Gainsborough }\end{array}$ & 5 \\
\hline 1793 & The Death of Marat & $\begin{array}{c}\text { painting of Jean-Paul Marat lying } \\
\text { dead in his bathtub by } \\
\text { Jacques-Louis David in } 1793\end{array}$ & 5 \\
\hline 1814 & Grande Odalisque & painting by Ingres & 5 \\
\hline 1819 & The Raft of the Medusa & painting by Théodore Géricault & 5 \\
\hline 1821 & The Hay Wain & painting by John Constable & 5 \\
\hline 1830 & Liberty Leading the People & painting by Eugène Delacroix & 5 \\
\hline 1834 & $\begin{array}{c}\text { The Martyrdom of Saint } \\
\text { Symphorian }\end{array}$ & $\begin{array}{l}\text { painting by Jean Auguste } \\
\text { Dominique Ingres }\end{array}$ & 5 \\
\hline 1851 & $\begin{array}{l}\text { Washington Crossing the } \\
\text { Delaware (1851 painting) }\end{array}$ & painting by Emanuel Leutze & 5 \\
\hline 1862 & $\begin{array}{c}\text { Symphony in White, No. 1: } \\
\text { The White Girl }\end{array}$ & $\begin{array}{c}\text { painting by James Abbott McNeill } \\
\text { Whistler }\end{array}$ & 5 \\
\hline 1875 & The Gross Clinic & painting by Thomas Eakins & 5 \\
\hline 1884 & Portrait of Madame X & $\begin{array}{c}\text { portrait painting by John Singer } \\
\text { Sargent }\end{array}$ & 5 \\
\hline 1897 & $\begin{array}{c}\text { Where Do We Come From? } \\
\text { What Are We? Where Are We } \\
\text { Going? }\end{array}$ & painting by Paul Gauguin & 5 \\
\hline 1907 & The Kiss (Klimt) & painting by Gustav Klimt & 5 \\
\hline 1911 & I and the Village & painting by Marc Chagall & 5 \\
\hline 1912 & $\begin{array}{l}\text { Nude Descending a } \\
\text { Staircase, No. } 2\end{array}$ & painting by Marcel Duchamp & 5 \\
\hline 1913 & Composition VII & painting by Wassily Kandinsky & 5 \\
\hline 1919 & The Ambassadors (Holbein) & $\begin{array}{c}\text { painting by Hans Holbein the } \\
\text { Younger }\end{array}$ & 5 \\
\hline 1923 & Bird in Space & sculpture by Constantin Brâncuși & 5 \\
\hline 1930 & American Gothic & painting by Grant Wood & 5 \\
\hline 1948 & Christina's World & painting by Andrew Wyeth & 5 \\
\hline 1330 & Navicella (mosaic) & mosaic by Giotto di Bondone & 5 \\
\hline 1470 & $\begin{array}{l}\text { Saint George and the Dragon } \\
\text { (Uccello) }\end{array}$ & 1470s painting by Uccello & 5 \\
\hline 1514 & The Feast of the Gods & $\begin{array}{c}\text { painting by Giovanni Bellini and } \\
\text { Titian }\end{array}$ & 5 \\
\hline
\end{tabular}




\begin{tabular}{|c|c|c|c|}
\hline 1537 & Portrait of Henry VIII & $\begin{array}{c}\text { lost painting by Hans Holbein the } \\
\text { Younger }\end{array}$ & 5 \\
\hline 1608 & $\begin{array}{c}\text { The Beheading of St John the } \\
\text { Baptist (Caravaggio) }\end{array}$ & painting by Caravaggio & 5 \\
\hline 1612 & $\begin{array}{c}\text { Judith Slaying Holofernes } \\
\text { (Artemisia Gentileschi, } \\
\text { Naples) }\end{array}$ & painting by Artemisia Gentileschi & 5 \\
\hline 1624 & The Rape of Proserpina & Sculpture by Gianlorenzo Bernini & 5 \\
\hline 1635 & Charles I in Three Positions & painting by Anthony van Dyck & 5 \\
\hline 1660 & The Four Seasons (Poussin) & $\begin{array}{l}\text { series of four paintings by } \\
\text { Nicolas Poussin }\end{array}$ & 5 \\
\hline 1667 & $\begin{array}{c}\text { Wanderer above the Sea of } \\
\text { Fog }\end{array}$ & $\begin{array}{l}\text { oil painting by Caspar David } \\
\text { Friedrich }\end{array}$ & 5 \\
\hline 1753 & Veiled Christ & $\begin{array}{l}\text { sculpture by Giuseppe } \\
\text { Sanmartino }\end{array}$ & 5 \\
\hline 1766 & The Swing (Fragonard) & $\begin{array}{l}\text { oil painting by Jean-Honoré } \\
\text { Fragonard (1767) }\end{array}$ & 5 \\
\hline 1801 & Napoleon Crossing the Alps & $\begin{array}{c}\text { series of paintings by } \\
\text { Jacques-Louis David in } 5 \\
\text { versions }\end{array}$ & 5 \\
\hline 1814 & The Third of May 1808 & painting by Francisco de Goya & 5 \\
\hline 1840 & The Slave Ship & $\begin{array}{c}\text { painting by Joseph Mallord } \\
\text { William Turner }\end{array}$ & 5 \\
\hline 1841 & Le Désespéré & painting by Gustave Courbet & 5 \\
\hline 1848 & Le génie du mal & $\begin{array}{l}\text { religious sculpture by Guillaume } \\
\text { Geefs }\end{array}$ & 5 \\
\hline 1851 & Ophelia (painting) & painting by John Everett Millais & 5 \\
\hline 1857 & The Gleaners & painting by Jean-François Millet & 5 \\
\hline 1858 & The Bellelli Family & painting by Edgar Degas & 5 \\
\hline 1859 & The Kiss (Hayez) & painting by Francesco Hayez & 5 \\
\hline 1870 & Barge Haulers on the Volga & painting by llya Repin & 5 \\
\hline 1877 & $\begin{array}{l}\text { Côte des Bœufs at } \\
\text { L'Hermitage }\end{array}$ & painting by Camille Pissarro & 5 \\
\hline 1880 & $\begin{array}{c}\text { Luncheon of the Boating } \\
\text { Party }\end{array}$ & $\begin{array}{c}\text { painting by Pierre-Auguste } \\
\text { Renoir }\end{array}$ & 5 \\
\hline 1884 & Bathers at Asnières & painting by Georges Seurat & 5 \\
\hline
\end{tabular}




\begin{tabular}{|c|c|c|c|}
\hline 1885 & Fabergé egg & $\begin{array}{c}\text { Jeweled Easter eggs mostly } \\
\text { commissioned by the Czar of } \\
\text { Russia }\end{array}$ & 5 \\
\hline 1887 & Girl with Peaches & painting by Valentin Serov & 5 \\
\hline 1887 & Luxembourg Gardens, Paris & painting by Albert Edelfelt & 5 \\
\hline 1890 & $\begin{array}{c}\text { At the Moulin Rouge, The } \\
\text { Dance }\end{array}$ & $\begin{array}{l}\text { painting by Henri de } \\
\text { Toulouse-Lautrec }\end{array}$ & 5 \\
\hline 1891 & Tiger in a Tropical Storm & painting by Henri Rousseau & 5 \\
\hline 1893 & The Card Players & painting series by Paul Cézanne & 5 \\
\hline 1895 & The Bronco Buster & sculpture by Frederic Remington & 5 \\
\hline 1898 & The Mature Age & sculpture by Camille Claudel & 5 \\
\hline 1909 & Dance (Matisse) & $\begin{array}{l}\text { two related paintings made by } \\
\text { Henri Matisse }\end{array}$ & 5 \\
\hline 1915 & Black Square (painting) & painting by Kazimir Malevich & 5 \\
\hline 1917 & Nu couché & painting by Amedeo Modigliani & 5 \\
\hline 1919 & Gassed (painting) & $\begin{array}{c}\text { oil painting by John Singer } \\
\text { Sargent }\end{array}$ & 5 \\
\hline 1920 & The Farm (Miró) & oil painting made by Joan Miró & 5 \\
\hline 1921 & The Elephant Celebes & surreal painting by Max Ernst & 5 \\
\hline 1922 & Twittering Machine & painting by Paul Klee & 5 \\
\hline 1926 & Black Iris (painting) & painting by Georgia O'Keeffe & 5 \\
\hline 1929 & The Treachery of Images & $\begin{array}{l}\text { painting by René Magritte } \\
\text { depicting a smoking pipe }\end{array}$ & 5 \\
\hline 1935 & $\begin{array}{c}\text { Composition with Red Blue } \\
\text { and Yellow }\end{array}$ & painting by Piet Mondrian & 5 \\
\hline 1947 & L'Homme au doigt & sculpture by Alberto Giacometti & 5 \\
\hline 1948 & No. 5,1948 & painting by Jackson Pollock & 5 \\
\hline 1948 & Family Group (Moore) & sculpture series by Henry Moore & 5 \\
\hline
\end{tabular}




\section{Non-Western Masterpieces}

\begin{tabular}{|c|c|c|c|c|}
\hline $\begin{array}{c}\text { Date of } \\
\text { Creatio } \\
\mathbf{n}\end{array}$ & Title & Artist & Place & Medium \\
\hline $1000-1600$ & Hoa Hakananai'a & $\begin{array}{c}\text { Hoa } \\
\text { Hakananai'a } \\
\text { islanders }\end{array}$ & $\begin{array}{c}\text { Easter } \\
\text { Island }\end{array}$ & $\begin{array}{c}\text { Sculpture, Flow lava } \\
\text { material }\end{array}$ \\
\hline $1037-1101$ & Wood and Rock & Su Shi & China & Ink, Colour/Paper \\
\hline 11 th & $\begin{array}{c}\text { Shaka rising from } \\
\text { the Gold Coffin }\end{array}$ & Unknown & Japan & $\begin{array}{c}\text { Hanging scroll, color } \\
\text { on silk }\end{array}$ \\
\hline $1100-1200$ & $\begin{array}{c}\text { Scrolls of } \\
\text { Frolicking } \\
\text { Animals and } \\
\text { Humans }\end{array}$ & Toba Sojo & Japan & ink and colors on \\
paper
\end{tabular}




\begin{tabular}{|c|c|c|c|c|}
\hline $\begin{array}{l}\text { 13-14th } \\
\text { Century }\end{array}$ & $\begin{array}{l}\text { Bronze Head } \\
\text { from Ife }\end{array}$ & Yoruba people & Nigeria & $\begin{array}{l}\text { Copper Alloy } \\
\text { Sculpture }\end{array}$ \\
\hline $1348-1420$ & $\begin{array}{c}\text { Dwellings in the } \\
\text { Fushun } \\
\text { Mountains }\end{array}$ & $\begin{array}{c}\text { Huang } \\
\text { Gongwang }\end{array}$ & China & Ink/Paper \\
\hline 1350 & $\begin{array}{c}\text { Zhichuan } \\
\text { Resettlement }\end{array}$ & Wang Meng & China & Ink/Paper \\
\hline $\begin{array}{l}\text { Early 14th } \\
\text { Century }\end{array}$ & $\begin{array}{l}\text { Rashid al-Din's } \\
\text { Compendium }\end{array}$ & $\begin{array}{l}\text { Rashid-al-Din } \\
\text { Hamadani }\end{array}$ & Persia & $\begin{array}{l}\text { Illustrated } \\
\text { manuscripts }\end{array}$ \\
\hline $\begin{array}{l}\text { 14th } \\
\text { Century }\end{array}$ & Nachi Falls & Unknown & Japan & $\begin{array}{l}\text { Hanging Scroll, } \\
\text { Colour on silk }\end{array}$ \\
\hline $\begin{array}{l}\text { Early 15th } \\
\text { Century }\end{array}$ & $\begin{array}{l}\text { Giant Uj and the } \\
\text { Prophets }\end{array}$ & Unknown & $\begin{array}{l}\text { Iraq or } \\
\text { Iran }\end{array}$ & $\begin{array}{l}\text { ink, gold and opaque } \\
\text { watercolour on paper }\end{array}$ \\
\hline $\begin{array}{l}15 \text { th/16th } \\
\text { century }\end{array}$ & $\begin{array}{c}\text { Codex } \\
\text { Borbonicus }\end{array}$ & Aztec priests & Mexico & Painting \\
\hline $\begin{array}{c}\text { 15th } \\
\text { Century }\end{array}$ & $\begin{array}{l}\text { Lamdre Lineage } \\
\text { (sculpture set) }\end{array}$ & $\begin{array}{l}\text { Khyentse } \\
\text { Chenmo }\end{array}$ & Tibet & Sculpture \\
\hline $\begin{array}{l}15 \text { th/16th } \\
\text { century }\end{array}$ & $\begin{array}{l}\text { Aztec Double } \\
\text { headed snake }\end{array}$ & Unknown & Mexico & Sculpture \\
\hline $\begin{array}{c}\text { 16th } \\
\text { Century }\end{array}$ & $\begin{array}{l}\text { Houghton } \\
\text { Shahnameh }\end{array}$ & $\begin{array}{l}\text { A wide variety } \\
\text { of artists with } \\
\text { many } \\
\text { specialties }\end{array}$ & $\begin{array}{c}\text { Iran } \\
\text { (Persia) }\end{array}$ & Manuscript \\
\hline $\begin{array}{c}\text { 16th } \\
\text { Century }\end{array}$ & $\begin{array}{c}\text { Alexander Visits } \\
\text { the Kaaba }\end{array}$ & Unknown & $\begin{array}{c}\text { Iran } \\
\text { (Persia) }\end{array}$ & $\begin{array}{l}\text { Opaque watercolor, } \\
\text { ink and gold on paper }\end{array}$ \\
\hline 1525-35 & $\begin{array}{l}\text { The Mi'raj or The } \\
\text { Night Flight of } \\
\text { Muhammad on } \\
\text { his Steed Buraq }\end{array}$ & $\begin{array}{c}\text { Sultan } \\
\text { Muhammad } \\
\text { Nur }\end{array}$ & $\begin{array}{c}\text { Iran } \\
\text { (Persia) }\end{array}$ & $\begin{array}{l}\text { Ink, gold, and colors } \\
\text { on paper }\end{array}$ \\
\hline $1539-40$ & $\begin{array}{l}\text { The Ardabil } \\
\text { Carpet }\end{array}$ & Unknown & $\begin{array}{c}\text { Iran } \\
\text { (Persia) }\end{array}$ & Carpet \\
\hline circa 1564 & $\begin{array}{c}\text { The Rukh Carries } \\
\text { Hamza to his } \\
\text { Home }\end{array}$ & $\begin{array}{l}\text { Daswant in } \\
\text { collaboration } \\
\text { with Shravan }\end{array}$ & India & $\begin{array}{c}\text { Opaque pigments on } \\
\text { canvas }\end{array}$ \\
\hline 1590s & $\begin{array}{c}\text { A Young Lady } \\
\text { Reclining After a } \\
\text { Bath }\end{array}$ & $\begin{array}{l}\text { Muhammad } \\
\text { Mu'min }\end{array}$ & Afganistan & $\begin{array}{c}\text { Ink, opaque } \\
\text { watercolor, and gold } \\
\text { on paper }\end{array}$ \\
\hline
\end{tabular}




\begin{tabular}{|c|c|c|c|c|}
\hline 1609-16 & $\begin{array}{l}\text { Ceiling of the } \\
\text { Blue Mosque }\end{array}$ & $\begin{array}{l}\text { Seyyid Kasim } \\
\text { Gubari }\end{array}$ & $\begin{array}{c}\text { Turkey } \\
\text { (Ottoman) }\end{array}$ & Painting on the ceiling \\
\hline 1626 & Youth reading & Reza Abbasi & $\begin{array}{c}\text { Iran } \\
\text { (Persia) }\end{array}$ & Miniature \\
\hline 1640 & $\begin{array}{c}\text { The Mazarin } \\
\text { Chest }\end{array}$ & Unknown & Japan & $\begin{array}{l}\text { Chest: wood covered } \\
\text { in black lacquer with } \\
\text { gold and silver } \\
\text { hiramakie and } \\
\text { takamakie lacquee }\end{array}$ \\
\hline 1698 & $\begin{array}{l}\text { The Virgin of } \\
\text { Guadalupe }\end{array}$ & $\begin{array}{c}\text { Miguel } \\
\text { Gonzalez }\end{array}$ & Mexico & $\begin{array}{c}\text { Painting, Oil/Canvas, } \\
\text { wood }\end{array}$ \\
\hline $\begin{array}{l}\text { 17th } \\
\text { Century }\end{array}$ & $\begin{array}{l}\text { Scene in and } \\
\text { around the } \\
\text { capital }\end{array}$ & Unknown & Japan & $\begin{array}{l}\text { Pair of six-panel } \\
\text { folding screens; ink, } \\
\text { color, gold, and gold } \\
\text { leaf on paper }\end{array}$ \\
\hline $\begin{array}{l}\text { 17th-18th } \\
\text { century }\end{array}$ & $\begin{array}{c}\text { Album of Mughal } \\
\text { Portraits }\end{array}$ & Jahangir & Mughal & $\begin{array}{l}\text { Brown morocco } \\
\text { binding with gilt } \\
\text { stamped medallions } \\
\text { and borders }\end{array}$ \\
\hline 1711 & $\begin{array}{c}\text { Album of Mount } \\
\text { Geumgang } \\
\text { (Pungak-docheop } \\
\text { ) }\end{array}$ & Jeong Seon & Korea & $\begin{array}{l}\text { Six leaves from a } \\
\text { fourteen-leaf album; } \\
\text { ink and light color on } \\
\text { silk }\end{array}$ \\
\hline $1740-50$ & $\begin{array}{c}\text { Marriage } \\
\text { Procession of } \\
\text { Dara Shikoh }\end{array}$ & Unknown & India & Painting \\
\hline 1751 & $\begin{array}{l}\text { Portraits of } \\
\text { Periodical } \\
\text { Offering }\end{array}$ & Xie Sui & China & Ink, Colour/Paper \\
\hline $1760-1780$ & $\begin{array}{c}\text { Ndop of king } \\
\text { Mishe miShyaang } \\
\text { maMbul }\end{array}$ & $\begin{array}{l}\text { Kuba people } \\
\text { of Central } \\
\text { Africa }\end{array}$ & $\begin{array}{l}\text { Democrati } \\
\text { c Republic } \\
\text { of the } \\
\text { Congo }\end{array}$ & Figurative Sculpture \\
\hline 1777 & $\begin{array}{l}\text { The Mexican } \\
\text { Castes }\end{array}$ & $\begin{array}{c}\text { Ignacio María } \\
\text { Barreda }\end{array}$ & Mexico & Painting, Oil/Canvas \\
\hline $\begin{array}{l}\text { 18th } \\
\text { Century }\end{array}$ & $\begin{array}{l}\text { Dalai Lama } \\
\text { Incarnation } \\
\text { Lineage }\end{array}$ & Unknown & Tibet & Paintings \\
\hline
\end{tabular}




\begin{tabular}{|c|c|c|c|c|}
\hline $1791-92$ & $\begin{array}{l}\text { Sitarah made for } \\
\text { the Mosque of } \\
\text { the Prophet in } \\
\text { Medina }\end{array}$ & Unknown & $\begin{array}{c}\text { Turkey } \\
\text { (Ottoman) }\end{array}$ & Textile \\
\hline $1809-10$ & $\begin{array}{l}\text { Portrait of Fath } \\
\text { Ali Shah } \\
\text { Standing }\end{array}$ & Mihr 'Ali & Persia & Painting, Oil/Canvas \\
\hline $1829-33$ & $\begin{array}{c}\text { The Great Wave } \\
\text { off Kanagawa }\end{array}$ & Hokusai & Japan & Color Woodblock \\
\hline 1845 & Mecca Panorama & $\begin{array}{l}\text { Muhammad } \\
\text { 'Abdallah }\end{array}$ & $\begin{array}{l}\text { Saudi } \\
\text { Arabia }\end{array}$ & $\begin{array}{c}\text { ink and opaque } \\
\text { watercolour on paper }\end{array}$ \\
\hline 1851 & $\begin{array}{c}\text { Portrait of } \\
\text { Manuelita Rosas }\end{array}$ & $\begin{array}{l}\text { Prilidiano } \\
\text { Pueyrredon }\end{array}$ & Argentina & Painting, Oil/Canvas \\
\hline 1857 & $\begin{array}{l}\text { The Arrest of } \\
\text { Pangeran } \\
\text { Diponegoro }\end{array}$ & Raden Saleh & Indonesia & Painting, Oil/Canvas \\
\hline $1867-76$ & Red silk mahmal & Unknown & Egypt & $\begin{array}{l}\text { mahmal cover, } \\
\text { banners and finial } \\
\text { banners of red silk }\end{array}$ \\
\hline 1870 & Shakuntala & $\begin{array}{l}\text { Raja Ravi } \\
\text { Verma }\end{array}$ & India & Painting, Oil/Canvas \\
\hline 1880 & $\begin{array}{l}\text { Girl Reciting } \\
\text { Qur'an }\end{array}$ & $\begin{array}{c}\text { Osman Hamdi } \\
\text { Bey }\end{array}$ & Turkey & Painting, Oil/Canvas \\
\hline 1880 & $\begin{array}{l}\text { Ledger drawing } \\
\text { of Haokah }\end{array}$ & Black Hawk & $\begin{array}{l}\text { United } \\
\text { States }\end{array}$ & Drawing \\
\hline 1887 & $\begin{array}{l}\text { The Maid } \\
\text { Awakens }\end{array}$ & Eduardo Sivori & Argentina & Painting, Oil/Canvas \\
\hline $1888-90$ & Waves & $\begin{array}{l}\text { Shibata } \\
\text { Zeshin }\end{array}$ & Japan & Painting, Oil/Canvas \\
\hline 1890 & $\begin{array}{l}\text { Pair of Samurai } \\
\text { Figures }\end{array}$ & Unknown & Japan & $\begin{array}{c}\text { bronze, thick gilding, } \\
\text { silver and shakudo }\end{array}$ \\
\hline 1893 & $\begin{array}{l}\text { Khalili Imperial } \\
\text { Garniture }\end{array}$ & $\begin{array}{l}\text { Japanese } \\
\text { Imperial } \\
\text { commission } \\
\text { during the } \\
\text { Meiji era }\end{array}$ & Japan & $\begin{array}{c}\text { Cloisonné enamel on } \\
\text { copper }\end{array}$ \\
\hline 1898 & Haremde Goethe & Abdulmejid II & Ottoman & Painting, Oil/Canvas \\
\hline
\end{tabular}




\begin{tabular}{|c|c|c|c|c|}
\hline 1899 & $\begin{array}{l}\text { The Doshan } \\
\text { Tappeh Street }\end{array}$ & Kamal-ol-molk & Persia & $\begin{array}{l}\text { Painting, Oil/Cotton } \\
\text { Duck }\end{array}$ \\
\hline 1905 & Bharat Matha & $\begin{array}{l}\text { Abindranath } \\
\text { Tagore }\end{array}$ & India & $\begin{array}{c}\text { Painting, } \\
\text { Watercolours }\end{array}$ \\
\hline $1922-25$ & Bed of Arrows & $\begin{array}{c}\text { Gaganendran } \\
\text { ath Tagore }\end{array}$ & India & $\begin{array}{c}\text { watercolour and } \\
\text { gouache on paper laic } \\
\text { on cardboard }\end{array}$ \\
\hline 1925 & $\begin{array}{l}\text { Twelve } \\
\text { Landscape } \\
\text { Screens }\end{array}$ & Qi Baishi & China & Ink, Colour/Paper \\
\hline 1925 & Bachué & Rómulo Rozo & Colombia & Granite Carving \\
\hline 1928 & $\begin{array}{c}\text { Farm } \\
\text { Jonkershoek with } \\
\text { Twin Peaks } \\
\text { Beyond, } \\
\text { Stellenbosch }\end{array}$ & $\begin{array}{c}\text { Jacob Hendrik } \\
\text { Pierneef }\end{array}$ & $\begin{array}{l}\text { South } \\
\text { Africa }\end{array}$ & Painting, Oil/Canvas \\
\hline $1929-35$ & $\begin{array}{c}\text { The History of } \\
\text { Mexico }\end{array}$ & Diego Rivera & Mexico & Mural \\
\hline 1930 & $\begin{array}{l}\text { Image actions } \\
\text { Mahatma Gandhi } \\
\text { (Bapuji) on the } \\
\text { Dandi March }\end{array}$ & Nandalal Bose & India & Linocut print on paper \\
\hline 1931 & $\begin{array}{c}\text { Construccion en } \\
\text { blanco }\end{array}$ & $\begin{array}{c}\text { Joaquín } \\
\text { Torres-García }\end{array}$ & Uruguay & Painting, Oil/Canvas \\
\hline 1933 & Self Portrait & $\begin{array}{l}\text { Amrita } \\
\text { Sher-Gil }\end{array}$ & India & Painting, Oil/Canvas \\
\hline 1934 & Les Chadoufs & $\begin{array}{l}\text { Mahmoud } \\
\text { Saiid }\end{array}$ & Egypt & Painting, Oil/Panel \\
\hline 1934 & $\begin{array}{l}\text { The People and } \\
\text { its Leaders }\end{array}$ & $\begin{array}{l}\text { José } \\
\text { Clemente } \\
\text { Orozco }\end{array}$ & Mexico & Mural \\
\hline 1935 & Maria Assumpta & $\begin{array}{l}\text { Basuki } \\
\text { Abdullah }\end{array}$ & Indonesia & Painting, Oil/Canvas \\
\hline 1936 & Birth of Fascism & $\begin{array}{l}\text { David Alfaro } \\
\text { Siqueiros }\end{array}$ & Mexico & $\begin{array}{l}\text { Painting, pyroxylin, } \\
\text { masonite }\end{array}$ \\
\hline $1940 \mathrm{~s}$ & Hill Fair & $\begin{array}{l}\text { Mookherjea } \\
\text { Sailoz }\end{array}$ & India & Painting, Oil/Card \\
\hline
\end{tabular}




\begin{tabular}{|c|c|c|c|c|}
\hline 1942 & The Barber Shop & $\begin{array}{l}\text { Cundo } \\
\text { Bermúdez }\end{array}$ & Cuba & Painting, Oil/Canvas \\
\hline 1943 & Little Girl Thuy & Tran Van Can & Vietnam & Painting, Oil/Canvas \\
\hline 1943 & Omi Obini & Wilfredo Lam & Cuba & Painting, Oil/Canvas \\
\hline 1944 & $\begin{array}{l}\text { Two Young Girls } \\
\text { and a Kid }\end{array}$ & To Ngoc Van & Vietnam & Painting, Oil/Canvas \\
\hline 1945 & Arab Priest & Irma Stern & $\begin{array}{l}\text { South } \\
\text { Africa }\end{array}$ & Painting, Oil/Canvas \\
\hline $1945-46$ & Glow of Hope & S.L. Haldankar & India & $\begin{array}{c}\text { Painting, } \\
\text { Watercolours }\end{array}$ \\
\hline 1946 & Ramayana & Jamini Roy & India & Painting, Oil/Canvas \\
\hline 1947 & $\begin{array}{l}\text { The Song of the } \\
\text { Pick }\end{array}$ & Gerard Sokoto & $\begin{array}{l}\text { South } \\
\text { Africa }\end{array}$ & Painting, Oil/Canvas \\
\hline 1948 & $\begin{array}{c}\text { Masacre del } 9 \text { de } \\
\text { abril }\end{array}$ & $\begin{array}{l}\text { Débora } \\
\text { Arango }\end{array}$ & Colombia & Painting, Oil/Canvas \\
\hline 1949 & Garden of Eden & $\begin{array}{l}\text { George } \\
\text { Pemba }\end{array}$ & $\begin{array}{l}\text { South } \\
\text { Africa }\end{array}$ & Painting, Oil/Board \\
\hline 1955 & Birth & F N Souza & Indian & Painting, Oil/Board \\
\hline 1959 & $\begin{array}{l}\text { Washing of the } \\
\text { feet }\end{array}$ & $\begin{array}{c}\text { Anita } \\
\text { Magsaysay - } \\
\text { Ho }\end{array}$ & $\begin{array}{l}\text { Philippine } \\
\text { s }\end{array}$ & Painting, Oil/Canvas \\
\hline $1960 s$ & $\begin{array}{c}\text { Blue } \\
\text { Composition }\end{array}$ & $\begin{array}{l}\text { Alexander } \\
\text { "Skunder" } \\
\text { Boghossian }\end{array}$ & Ethiopia & $\begin{array}{c}\text { Acrylic, gouache and } \\
\text { air brush on panel in } \\
\text { artist's frame }\end{array}$ \\
\hline 1960 & Horses & M.F. Husain & India & Painting, Oil/Canvas \\
\hline 1961 & $\begin{array}{l}\text { Man Carrying } \\
\text { Reluctant Wife }\end{array}$ & Pudlo Pudlat & Canada & $\begin{array}{c}\text { Drawing-Watercolor, } \\
\text { Stencil }\end{array}$ \\
\hline 1961 & $\begin{array}{l}\text { Self-Portrait of } \\
\text { Suffering }\end{array}$ & $\begin{array}{l}\text { Ibrahim } \\
\text { El-Salahi }\end{array}$ & Sudan & Painting, Oil/Canvas \\
\hline 1962 & Metro Ride & Demas Nwoko & Nigeria & Painting, Oil/Canvas \\
\hline 1965 & Adam and Eve & Uche Okeke & Nigeria & Painting, Oil/Board \\
\hline 1965 & $\begin{array}{l}\text { The Construction } \\
\text { of the Suez Canal }\end{array}$ & $\begin{array}{l}\text { Abdul Hadi } \\
\text { El-Gazzar }\end{array}$ & Egypt & $\begin{array}{c}\text { Watercolour, gouache } \\
\text { and ink on paper }\end{array}$ \\
\hline $1969-89$ & $\begin{array}{l}\text { Centre South } \\
\text { North Spring } \\
\text { Garden }\end{array}$ & $\begin{array}{c}\text { Nguyễn Gia } \\
\text { Trí }\end{array}$ & Vietnam & Painting, Oil/Canvas \\
\hline
\end{tabular}




\begin{tabular}{|c|c|c|c|c|}
\hline 1971 & $\begin{array}{l}\text { Honey ant } \\
\text { dreaming }\end{array}$ & $\begin{array}{c}\text { Kaapa } \\
\text { Tjampitjinpa }\end{array}$ & Australia & Mural \\
\hline 1973 & $\begin{array}{c}\text { Beef Issue at Fort } \\
\text { Sill }\end{array}$ & T. C. Cannon & $\begin{array}{l}\text { United } \\
\text { States }\end{array}$ & Acrylic on Canvas \\
\hline 1973 & Tutu & Ben Enwonwu & Nigeria & Print Multiple \\
\hline 1973 & $\begin{array}{c}\text { Sadequain Mural } \\
\text { - Quest for } \\
\text { Knowledge }\end{array}$ & Sadequain & Pakistan & Painting, Oil/Canvas \\
\hline 1977 & Warlugulong & $\begin{array}{l}\text { Clifford } \\
\text { Possum } \\
\text { Tjapaltjarri }\end{array}$ & Australia & Painting, Oll/Canvas \\
\hline 1977 & $\begin{array}{c}\text { Defender of His } \\
\text { Country }\end{array}$ & Afewerk Tekle & Ethiopia & Painting, Oil/Canvas \\
\hline 1980 & Bindu & S.H. Raza & India & $\begin{array}{c}\text { Serigraph (Silk } \\
\text { Screen on Paper) }\end{array}$ \\
\hline 1984 & Five Stories & $\begin{array}{l}\text { Michael } \\
\text { Nelson } \\
\text { Jagamara }\end{array}$ & Australia & Painting, Oll/Canvas \\
\hline 1986 & $\begin{array}{c}\text { Silent in Our } \\
\text { Beauty We Stand }\end{array}$ & Daphne Odjig & Canada & $\begin{array}{c}\text { Painting, } \\
\text { Acrylic/canvas }\end{array}$ \\
\hline 1990 & Lament & Allan Houser & $\begin{array}{l}\text { United } \\
\text { States }\end{array}$ & Sculpture, Bronze \\
\hline 1991 & $\begin{array}{c}\text { Kame- Summer } \\
\text { Awelye II }\end{array}$ & $\begin{array}{l}\text { Emily Kame } \\
\text { Kngwarreye }\end{array}$ & Australia & Painting, Oll/Canvas \\
\hline 1992 & Sarajevo & Omar El-Nagdi & Egypt & $\begin{array}{c}\text { oil on canvas, in three } \\
\text { parts }\end{array}$ \\
\hline
\end{tabular}

\section{Artist coverage ratios for some Wikipedias}

Higher numbers mean more focus given to Western artists; lower numbers mean the coverage is more "global".

\begin{tabular}{|l|l|r|r|r|}
\hline Language & $\begin{array}{l}\text { Langua } \\
\text { ge code }\end{array}$ & $\begin{array}{r}\text { Western artists } \\
\text { (bytes) }\end{array}$ & $\begin{array}{r}\text { Non-Western } \\
\text { artists } \\
\text { (bytes) }\end{array}$ & Ratio \\
\hline Thai & th & 1577064 & 37777 & 41.75 \\
\hline Asturian & ast & 1919617 & 67649 & 28.38 \\
\hline
\end{tabular}




\begin{tabular}{|c|c|c|c|c|}
\hline Danish & da & 844509 & 29857 & 28.29 \\
\hline Lithuanian & It & 1052747 & 38249 & 27.52 \\
\hline Croatian & $\mathrm{hr}$ & 856295 & 31519 & 27.17 \\
\hline $\begin{array}{l}\text { Belarusian (Taraškievica } \\
\text { orthography) }\end{array}$ & be-tarask & 616393 & 23751 & 25.95 \\
\hline Afrikaans & af & 810092 & 31723 & 25.54 \\
\hline Estonian & et & 1035236 & 45392 & 22.81 \\
\hline Maltese & $\mathrm{mt}$ & 474881 & 22481 & 21.12 \\
\hline Slovene & sl & 1240942 & 60240 & 20.60 \\
\hline Finnish & $\mathrm{fi}$ & 1131659 & 57190 & 19.79 \\
\hline Greek & el & 1754996 & 91687 & 19.14 \\
\hline Serbo-Croatian & sh & 870333 & 48966 & 17.77 \\
\hline Chechen & ce & 632678 & 36870 & 17.16 \\
\hline Bokmål & $\mathrm{nb}$ & 865480 & 58757 & 14.73 \\
\hline Romanian & ro & 1125666 & 76623 & 14.69 \\
\hline Galician & gl & 1560347 & 106539 & 14.65 \\
\hline Italian & it & 3846109 & 279501 & 13.76 \\
\hline Georgian & ka & 923232 & 70247 & 13.14 \\
\hline Tarantino & it-x-tara & 339477 & 26214 & 12.95 \\
\hline Belarusian & be & 1674464 & 129302 & 12.95 \\
\hline Nynorsk & $\mathrm{nn}$ & 313037 & 24588 & 12.73 \\
\hline Serbian & $\mathrm{sr}$ & 1877184 & 147803 & 12.70 \\
\hline Bulgarian & bg & 1713494 & 137441 & 12.47 \\
\hline Bashkir & ba & 1026273 & 84497 & 12.15 \\
\hline Polish & $\mathrm{pl}$ & 1856378 & 157538 & 11.78 \\
\hline Esperanto & eo & 1055956 & 91345 & 11.56 \\
\hline Simple English & en-simple & 478046 & 43888 & 10.89 \\
\hline Hungarian & hu & 1553127 & 152783 & 10.17 \\
\hline Swedish & sv & 818566 & 82437 & 9.93 \\
\hline Hebrew & he & 1243742 & 137012 & 9.08 \\
\hline Latin & la & 354863 & 39975 & 8.88 \\
\hline Burmese & my & 277540 & 31299 & 8.87 \\
\hline Macedonian & $\mathrm{mk}$ & 976674 & 112845 & 8.66 \\
\hline
\end{tabular}




\begin{tabular}{|c|c|c|c|c|}
\hline Turkish & tr & 1130276 & 133821 & 8.45 \\
\hline Portuguese & pt & 1822828 & 216634 & 8.41 \\
\hline Japanese & ja & 2893884 & 344564 & 8.40 \\
\hline Czech & cs & 1685339 & 204217 & 8.25 \\
\hline German & de & 4513825 & 555219 & 8.13 \\
\hline Spanish & es & 4202760 & 517974 & 8.11 \\
\hline Basque & eu & 922139 & 118435 & 7.79 \\
\hline Korean & ko & 817959 & 106942 & 7.65 \\
\hline Dutch & $\mathrm{nl}$ & 1636039 & 228762 & 7.15 \\
\hline French & fr & 6235180 & 876287 & 7.12 \\
\hline Malayalam & $\mathrm{ml}$ & 1374045 & 205898 & 6.67 \\
\hline Catalan & $\mathrm{ca}$ & 2254534 & 341903 & 6.59 \\
\hline Tamil & ta & 807774 & 130211 & 6.20 \\
\hline Welsh & cy & 391141 & 68955 & 5.67 \\
\hline Azerbaijani & az & 582431 & 104254 & 5.59 \\
\hline Russian & ru & 5330034 & 958510 & 5.56 \\
\hline Quechua & qu & 123473 & 23071 & 5.35 \\
\hline Vietnamese & vi & 1042035 & 194942 & 5.35 \\
\hline Chinese & $\mathrm{zh}$ & 1274771 & 242399 & 5.26 \\
\hline Arabic & ar & 1401071 & 267791 & 5.23 \\
\hline Mongolian & $\mathrm{mn}$ & 182916 & 39047 & 4.68 \\
\hline Tuvan & tyv & 141294 & 30547 & 4.63 \\
\hline Ukrainian & uk & 2797317 & 614581 & 4.55 \\
\hline Bavarian & bar & 187597 & 44027 & 4.26 \\
\hline Armenian & hy & 2239028 & 530142 & 4.22 \\
\hline Persian & fa & 1634226 & 392738 & 4.16 \\
\hline Scots & sco & 84459 & 20599 & 4.10 \\
\hline Kazakh & kk & 271106 & 68156 & 3.98 \\
\hline English & en & 5927835 & 1494254 & 3.97 \\
\hline Uzbek & uz & 88073 & 23337 & 3.77 \\
\hline llocano & ilo & 91575 & 24379 & 3.76 \\
\hline Indonesian & id & 565859 & 171585 & 3.30 \\
\hline Egyptian Arabic & arz & 109731 & 34582 & 3.17 \\
\hline
\end{tabular}




\begin{tabular}{|l|l|r|r|r|}
\hline Tagalog & $\mathrm{tl}$ & 72327 & 24203 & 2.99 \\
\hline Hindi & $\mathrm{hi}$ & 337095 & 121612 & 2.77 \\
\hline Kannada & $\mathrm{kn}$ & 589153 & 233009 & 2.53 \\
\hline Malay & $\mathrm{ms}$ & 215268 & 92333 & 2.33 \\
\hline Santali & sat & 87847 & 38464 & 2.28 \\
\hline Western Armenian & hyw & 292330 & 135260 & 2.16 \\
\hline Punjabi & pa & 340529 & 177997 & 1.91 \\
\hline Assamese & as & 205877 & 109196 & 1.89 \\
\hline Bengali & bn & 598682 & 343743 & 1.74 \\
\hline Kyrgyz & ky & 86522 & 50137 & 1.73 \\
\hline Marathi & mr & 186189 & 116482 & 1.60 \\
\hline Gujarati language & gu & 221480 & 165210 & 1.34 \\
\hline Western Punjabi & pnb & 131598 & 106697 & 1.23 \\
\hline Maithili & mai & 21493 & 22838 & 0.94 \\
\hline Nepali & ne & 23021 & 31253 & 0.74 \\
\hline Odia & or & 58447 & 79614 & 0.73 \\
\hline Tajik & tg & 25632 & 41554 & 0.62 \\
\hline Urdu & ur & 65583 & 110819 & 0.59 \\
\hline Telugu & te & 21206 & 106810 & 0.20 \\
\hline & & & \\
\hline
\end{tabular}

\section{Examples of major national museums and art galleries outside the Western world (including indigenous art institutions in the West)}

\begin{tabular}{|l|l|l|}
\hline Name & Country & Link \\
\hline $\begin{array}{l}\text { Art Gallery of New South } \\
\text { Wales }\end{array}$ & Australia & https://www.artgallery.nsw.gov.au/ \\
\hline $\begin{array}{l}\text { Bangkok Art and Culture } \\
\text { Centre }\end{array}$ & Thailand & https://www.bacc.or.th/ \\
\hline Bardo Museum & Tunisia & http://www.bardomuseum.tn/ \\
\hline Capital Museum & China & http://en.capitalmuseum.org.cn/ \\
\hline
\end{tabular}




\begin{tabular}{|c|c|c|}
\hline $\begin{array}{l}\text { Centro Cultural Banco do } \\
\text { Brasil }\end{array}$ & Brazil & $\begin{array}{l}\text { https://www.bb.com.br/pbb/pagina-inicial/ } \\
\text { sobre-nos/cultura/ccbb }\end{array}$ \\
\hline $\begin{array}{l}\text { Chilean National Museum } \\
\text { of Fine Arts }\end{array}$ & Chile & $\begin{array}{l}\text { https://www.mnba.gob.cl/sitio/Contenido/ } \\
\text { Colecciones-digitales/87330:Itinerario-de- } \\
\text { la-coleccion-del-MNBA }\end{array}$ \\
\hline Egyptian Museum & Egypt & $\begin{array}{l}\text { https://web.archive.org/web/20171023043 } \\
\text { o06/http://www.sca-egypt.org/eng/mus e } \\
\text { gyptian museum.htm }\end{array}$ \\
\hline $\begin{array}{l}\text { Hanoi Contemporary Arts } \\
\text { Centre }\end{array}$ & Vietnam & $\begin{array}{l}\text { https://web.archive.org/web/20080103094 } \\
\text { 509/http://www.iapone.org/Pages/Hanoi } \\
\text { Contemp Arts Ctr.html }\end{array}$ \\
\hline Iroquois Indian Museum & United States & $\begin{array}{l}\text { https://iroquoismuseum.pastperfectonline. } \\
\underline{\text { com/ }}\end{array}$ \\
\hline Israel Museum & Israel & https://www.imj.org.il/en \\
\hline $\begin{array}{l}\text { Istanbul Museum of } \\
\text { Modern Art }\end{array}$ & Turkey & https://www.istanbulmodern.org/en \\
\hline $\begin{array}{l}\text { Jordan National Gallery of } \\
\text { Fine Arts }\end{array}$ & Jordan & https://nationalgallery.org/ \\
\hline Matarazzo Ciccillo (Bienal) & Brazil & http://www.bienal.org.br/pavilion \\
\hline MMCA, Gwacheon & South Korea & $\begin{array}{l}\text { https://www.mmca.go.kr/eng/contents.do? } \\
\text { menuld=5050011511 }\end{array}$ \\
\hline $\begin{array}{l}\text { Museum of Contemporary } \\
\text { African Diasporan Arts }\end{array}$ & United States & https://mocada.org/digital \\
\hline $\begin{array}{l}\text { Museum of International } \\
\text { Folk Art }\end{array}$ & United States & $\begin{array}{l}\text { http://collection.internationalfolkart.org/coll } \\
\text { ections:jsessionid=8DD6AF94A2B04425 } \\
\underline{\text { C65DF97FC4188168 }}\end{array}$ \\
\hline Museum of Islamic Art & Egypt & https://www.miaegypt.org/ \\
\hline Museum of New Zealand & New Zealand & https://collections.tepapa.govt.nz/ \\
\hline Nairobi National Museum & Kenya & https://www.kenyamuseumsociety.org/ \\
\hline National Art Gallery & Pakistan & https://pnca.org.pk/galleries \\
\hline $\begin{array}{l}\text { National Gallery of Modern } \\
\text { Art }\end{array}$ & India & http://ngmaindia.gov.in/ \\
\hline $\begin{array}{l}\text { National Gallery of Modern } \\
\text { Art }\end{array}$ & Nigeria & $\begin{array}{l}\text { https://web.archive.org/web/20101126030 } \\
\text { 128/http://nigeria-vacation.com/users/profi } \\
\text { les.php?id_usr=186\&tong=3 }\end{array}$ \\
\hline National Gallery of Victoria & Australia & https://www.ngv.vic.gov.au/ \\
\hline National Gallery of & Zimbabwe & http://www.nationalgallery.co.zw/ \\
\hline
\end{tabular}




\begin{tabular}{|c|c|c|}
\hline Zimbabwe & & \\
\hline National Gallery Singapore & Singapore & https://www.nationalgallery.sg/ \\
\hline $\begin{array}{l}\text { National Museum of } \\
\text { Anthropology }\end{array}$ & Mexico & https://www.mna.inah.gob.mx/ \\
\hline National Museum of China & China & http://en.chnmuseum.cn/ \\
\hline $\begin{array}{l}\text { National Museum of Fine } \\
\text { Arts }\end{array}$ & Philippines & $\begin{array}{l}\text { http://www.nationalmuseum.gov.ph/\#page } \\
=\text { page-1 }\end{array}$ \\
\hline $\begin{array}{l}\text { National Museum of Fine } \\
\text { Arts of Algiers }\end{array}$ & Algeria & http://www.musee-beauxarts.dzl \\
\hline $\begin{array}{l}\text { National Museum of } \\
\text { Indonesia }\end{array}$ & Indonesia & https://www.museumnasional.or.id/ \\
\hline National Museum of Iraq & Iraq & https://www.theiraqmuseum.com/ \\
\hline National Museum of Korea & South Korea & https://www.museum.go.kr/site/eng/home \\
\hline $\begin{array}{l}\text { National Museum of } \\
\text { Modern and Contemporary } \\
\text { Art }\end{array}$ & South Korean & https://www.mmca.go.kr/eng/ \\
\hline National Museum of Sudan & Sudan & http://sudannationalmuseum.com/ \\
\hline National Palace Museum & Taiwan & https://www.npm.gov.tw/en/ \\
\hline $\begin{array}{l}\text { National Taiwan Museum } \\
\text { of Fine Arts }\end{array}$ & Taiwan & https://www.ntmofa.gov.tw/en/ \\
\hline $\begin{array}{l}\text { National Visual Arts Gallery } \\
\text { (Malaysia) }\end{array}$ & Malaysia & $\begin{array}{l}\text { https://www.artgallery.gov.my/?page id=1 } \\
\text { 5\&lang=en }\end{array}$ \\
\hline Patan Museum & Nepal & http://www.patanmuseum.gov.np/ \\
\hline $\begin{array}{l}\text { Queensland Gallery of } \\
\text { Modern Art }\end{array}$ & Australia & https://www.qagoma.qld.gov.au/ \\
\hline Rwanda Art Museum & Rwanda & $\begin{array}{l}\text { https://www.museum.gov.rw/index.php?id } \\
=74\end{array}$ \\
\hline Salar Jung Museum & India & http://www.salarjungmuseum.in/ \\
\hline Shandong Art Museum & China & http://www.sdam.org.cn// \\
\hline Shanghai Museum & China & $\begin{array}{l}\text { https://www.shanghaimuseum.net/mu/fron } \\
\text { tend/pg/index }\end{array}$ \\
\hline $\begin{array}{l}\text { Shangri La Museum of } \\
\text { Islamic Art, Culture \& } \\
\text { Design }\end{array}$ & Hawaii & $\begin{array}{l}\text { https://collection.shangrilahawaii.org/galle } \\
\text { ry }\end{array}$ \\
\hline Sharjah Art Museum & UAE & https://www.sharjahartmuseum.ae/ \\
\hline South Africa National & South Africa & https://www.iziko.org.za/museums/south- \\
\hline
\end{tabular}




\begin{tabular}{|l|l|l|}
\hline Gallery & & african-national-gallery \\
\hline Sursock Museum & Lebanon & https://sursock.museum/ \\
\hline Tel Aviv Museum of Art & Israel & https://www.tamuseum.org.il/en/ \\
\hline $\begin{array}{l}\text { The Latin American Art } \\
\text { Museum of Buenos Aires } \\
\text { (MALBA) }\end{array}$ & Argentina & https://coleccion.malba.org.ar/ \\
\hline The Museum of Islamic Art & Qatar & http://www.mia.org.qa/en/ \\
\hline $\begin{array}{l}\text { The National Museum of } \\
\text { Iran }\end{array}$ & Iran & http://gallery.netbaran.com/museum-Natio \\
\hline $\begin{array}{l}\text { Tokyo Metropolitan Art } \\
\text { Museum }\end{array}$ & Japan & https://www.tobikan.jp/en/ \\
\hline Tokyo National Art Center & Japan & https://www.nact.jp/english/ \\
\hline
\end{tabular}

\section{Select Bibliography}

- Modern Art in Africa, Asia and Latin America: An Introduction to Global Modernisms Paperback - 31 July 2012 by O'Brien

- Masters of Indian Painting, 1100-1900 (Supplementum Series) Hardcover Illustrated, 1 Jun. 2011

- Wonder of the age: master painters of India, 1100-1900 - John Guy 2011

- Forgotten masters. Indian painting for the East India Company. William Darymple 2019

- The Spirit of Indian Painting: Close Encounters with 101 Great Works 1100 -1900 Hardcover - Illustrated, 29 Feb. 2016 


\section{Acknowledgements}

This research was supported by a grant from Wikimedia UK. We are grateful to Daria Cybulska, Wikimedia UK's Director of Programmes and Evaluation, for comments on a draft of this paper. Any errors or omissions are the fault of the authors.

\section{Experts consulted}

- Professor Christian Luczanits, SOAS - Himalayan Art

- Professor McCausland, SOAS - Chinese and East Asian art

- Professor Chika Okeke-Agulu, Princeton University - African art

- Professor Crispin Branfoot, SOAS - Indian art

- Professor Sir Nasser David Khalili, The Khalili Collections - Islamic and Japanese art

- Professor Maria Madero, London Interdisciplinary School - Latin American art

- Dr Heather Igloliorte, Concordia University - North American indigenous art

\section{Competing interests}

Waqas Ahmed is the Artistic Director at the Khalili Collections and is on the steering panel of Art UK.

Martin Poulter is a freelance consultant working on partnerships between Wikimedia and cultural institutions.

\section{Author roles}

Authors are listed in descending order by significance of contribution. The corresponding author is wa. Roles in the CRediT Contributor Roles Taxonomy:

\begin{tabular}{|l|l|}
\hline Conceptualization & wa \\
\hline Data curation & $\mathrm{mp}$ \\
\hline Formal analysis & $\mathrm{mp}$ \\
\hline Funding acquisition & wa \\
\hline Investigation & wa, $\mathrm{mp}$ \\
\hline Methodology & $\mathrm{mp}$ \\
\hline Project administration & wa, mp \\
\hline Software & $\mathrm{mp}$ \\
\hline
\end{tabular}




\begin{tabular}{|l|l|}
\hline Validation & $\mathrm{mp}$ \\
\hline Visualization & wa,mp \\
\hline Writing - original draft & wa,mp \\
\hline Writing - review \& editing & wa,mp \\
\hline
\end{tabular}




\section{Works cited}

Callahan, Ewa S., and Susan C. Herring. 'Cultural Bias in Wikipedia Content on Famous Persons'. Journal of the American Society for Information Science and Technology 62, no. 10 (October 2011): 1899-1915.

https://doi.org/10.1002/asi.21577.

Dolmaya, Julie McDonough. 'Expanding the Sum of All Human Knowledge: Wikipedia, Translation and Linguistic Justice'. The Translator 23, no. 2 (2017): 143-57. https://doi.org/10.1080/13556509.2017.1321519.

Graham, M., S. A. Hale, and M. Stephens. 'Geographies of the World's Knowledge'. Edited by C M. Flick. Oxford Internet Institute, University of Oxford, 2011.

https://www.oii.ox.ac.uk/archive/downloads/publications/convoco geographi es en.pdf.

Graham, Mark, and Matthew Zook. 'Augmented Realities and Uneven

Geographies: Exploring the Geolinguistic Contours of the Web'.

Environment and Planning A 45 (2013): 77-99.

https://doi.org/10.1068/a44674.

Maher, Katherine, and Loic Tallon. 'Wikimedia and The Met: A Shared Digital Vision'. Metropolitan Museum of Art, 19 April 2018.

https://www.metmuseum.org/blogs/now-at-the-met/2018/wikimedia-and-themet-digital-vision.

Maurer, Hermann, and Josef Kolbitsch. 'The Transformation of the Web: How Emerging Communities Shape the Information We Consume'. Journal of Universal Computer Science 12, no. 2 (2006): 187-213.

https://doi.org/10.3217/JUCS-012-02-0187.

MediaWiki contributors. 'API:Main Page'. MediaWiki. Accessed 24 January 2021. https://www.mediawiki.org/wiki/API:Main_page.

Meta contributors. 'Wikimedia Movement 2017 Strategy/ Direction'. Meta, discussion about Wikimedia projects. Accessed 24 January 2021.

https://meta.wikimedia.org/wiki/Strategy/Wikimedia movement/2017/Directio $\underline{\mathrm{n}}$.

. 'Wikimedia Movement Strategy Recommendations'. Meta, discussion about Wikimedia projects. Accessed 4 January 2021.

https://meta.wikimedia.org/wiki/Strategy/Wikimedia movement/2018-20/Rec ommendations/Identify Topics for Impact. 
. 'Wikimedian in Residence'. Meta, discussion about Wikimedia projects. Accessed 24 January 2021.

https://meta.wikimedia.org/wiki/Wikimedian_in_residence.

OpenGLAM Working Group. 'OpenGLAM Principles, Version 1.0', 2011.

https://openglam.org/principles/.

Orlowitz, Jake. 'The Wikipedia Library'. In Leveraging Wikipedia: Connecting

Communities of Knowledge, edited by Merrilee Proffitt, 69-86. American Library Association, 2018.

Outreach Wiki contributors. 'GLAM/Repository'. Outreach Wiki. Accessed 4 January 2021. https://outreach.wikimedia.org/wiki/GLAM/Repository.

_. 'GLAM-WIKI'. Outreach Wiki. Accessed 24 January 2021.

https://outreach.wikimedia.org/wiki/GLAM.

Wikimedia Commons contributors. 'Commons:Guide to Content Partnerships'.

Wikimedia Commons. Accessed 4 January 2021.

https://commons.wikimedia.org/wiki/Commons:Guide to content partnershi ps.

Wikipedia contributors. 'Help:Adding Open License Text to Wikipedia'. Wikipedia. Accessed 4 January 2021.

https://en.wikipedia.org/wiki/Help:Adding_open_license_text_to_Wikipedia.

—. 'Wikipedia:Vital Articles'. Wikipedia. Accessed 1 November 2020.

https://en.wikipedia.org/wiki/Wikipedia:Vital articles.

- 'Wikipedia:WikiProject Women in Red'. Wikipedia. Accessed 4 January

2021. https://en.wikipedia.org/wiki/Wikipedia:WikiProject Women in Red. 